\title{
Una discusión humanista inaplazable: la persona frente a la ley. Reflexiones bíblico-teológicas de razón hinkelammertiana
}

Loida Sardiñas Iglesias*

\section{Resumen}

El artículo profundiza bíblico-teológicamente la interpretación hinkelammertiana de algunos paradigmas bíblicos que abordan la relación de la persona con la ley (tradición abrahámica, mosaica pre-exílica y mosaica post-exílica), con el objeto de reivindicar la centralidad de la persona como el lugar verdadera y auténticamente humano desde el cual discernir todo tipo de ley y hacerla reflexiva frente a la vida humana.

\section{Palabras claves}

Persona, ley, cultura occidental, teología bíblica veterotestamentaria, tradición mosaica. 


\title{
A Humanist Discussion Urgent: the Person Before the Law. Biblical-theological Reflections to Reason of Hinkelammert
}

\begin{abstract}
The article explores biblical-theologically the Hinkeklammert's interpretation of two biblical paradigms that argue the relationship of the person with the law: the Abrahamic tradition and the pre-exilic Mosaic tradition, and the post-exilic Mosaic tradition. This, in order to demand the centrality of the person, as truly and authentic human place from which to discern all kind of law and make it reflective with respect to human life.
\end{abstract}

\section{Keywords}

Person, law, Western culture, Old Testament theology, Mosaic tradition.

\section{Introducción}

En el marco de las discusiones sobre la centralidad de la persona al interior del humanismo cristiano, postulado con posterioridad al llamado giro antropológico, resulta de crucial importancia el tema de la relación que se establece entre el ser humano y la ley. Una relación sin dudas, compleja, no unívoca, que afecta al ser humano en sus vinculaciones inmediatas y mediatas, comunitarias, institucionales y sociales, y cuya tematización no resulta del todo novedosa. Por una parte, las preguntas por el Sein (ser), Wesen (esencia) y Dasein (existencia) del ser humano, por el carácter humano o de humanidad del hombre y por los signos de humanidad o inhumanidad que atraviesan la condición humana, han ocupado largamente la reflexión 
antropo-teológica cristiana humanista de los últimos tiempos ${ }^{1}$. Se trata de preguntas tan antiguas como el ser humano mismo, pero que adquieren en el contexto teológico una dimensión trascendental, en tanto se afirma al ser humano en su carácter de persona, con toda la carga de autonomía, autocerteza, relacionabilidad y potencialidad que ello implica.

Por otra parte, este ser humano-persona que afirma la antropología humanista y que «antes que nada se hace» (Bloch), solo puede «hacerse», autoconstituirse como sujeto, en el marco de relaciones comunitarias y sociales, en el «vital tejido de relaciones de reconocimiento recíproco, en las que solo mutuamente pueden las personas estabilizar su quebradiza identidad $»^{2}$. En las modernas sociedades complejas, este tipo de nexo vital o relacionamiento y reconocimiento social, exige un marco de institucionalidad de las relaciones sociales que se encuentra atravesado inevitablemente por una lógica normativa o regulativa de la dinámica social, necesaria para el llamado «ordenamiento» de la estructura social. La persona se encuentra, entonces, cotidiana y necesariamente enfrentada a una permanente relación con leyes -sean del tipo que sean, disposiciones de tipo consuetudinario o normas jurídicas-, las cuales tienen como horizonte de sentido afirmar la vida humana, posibilitar la sobrevivencia humana, hacer factible que el ser humano pueda vivir en sociedad. Lo que en términos teológicos significa que la ley ha sido creada para el ser humano y tiene como finalidad contribuir al bien común (Santo Tomás).

Sin embargo, el tipo de organización social que se ha venido configurando en los últimos decenios absolutiza determinadas leyes sociales y sacraliza determinadas relaciones y organizaciones socia-

1 Cf. J. Moltmann, Antropología cristiana en los conflictos del presente (Salamanca: Sígueme, 1980); W. Pannenberg, El hombre como problema (Barcelona: Herder, 1976) y Antropología en perspectiva teológica (Salamanca: Sígueme, 1993); J. L. Ruiz de la Peña, Imagen de Dios: antropología teológica fundamental (Santander: Sal Terrae, 1988). L. F. Ladaria, Introducción a la antropología teológica (Navarra: Verbo Divino, 2004); A. Scola, Cuestiones de Antropología teológica (Madrid: BAC, 2000) y Antropología teológica. La persona humana (Valencia: Edicep, 2003).

2 J. Habermas, Aclaraciones a la Ética del Discurso (Buenos Aires: Libros Tauro, 2000), 27. 
les normativas por encima de la persona humana. Ésta se enfrenta cotidianamente a normas y leyes de un contexto globalizado, que han venido produciendo a nivel macro y micro-social crisis en la vida humana y en la naturaleza en la mayoría de las regiones del planeta. Se trata fundamentalmente de: (a) leyes económicas mundiales que excluyen y fragilizan aún más las economías de los países, grupos sociales e individuos más vulnerables; (b) normatividades políticas que configuran un «imperio mundial» que debilita cada día más la soberanía de las naciones; (c) códigos y patrones culturales globales, funcionales al orden económico y político vigente, que reducen al mínimo y folklorizan las culturas nacionales y originarias; (d) disposiciones religiosas igualmente globalizadas, que fortalecen las corrientes neo-conservadoras y fundamentalistas en el mundo cristiano y promueven concepciones teológicas mercantilistas. Tales leyes y normatividades no suponen una exterioridad al ser humano, sino que afectan y están a la base del «autoconstituirse» de la persona en la esfera de su existencia.

Frente a estas leyes económicas, políticas, culturales y religiosas de carácter normativo, que interpelan los criterios teológicos centrales de humanidad y humanización de la vida, se impone una comprensión crítica del criterio de centralidad de la persona individual y en sus relaciones vitales sociales. El presente artículo pretende asumir la centralidad de la persona frente a toda ley de cumplimiento formal, desde una perspectiva bíblico-teológica, tomando en cuenta los aportes del teólogo y economista Franz Hinkelammert. Para hacerlo, se intentará incursionará en el campo de la teología bíblica a través del acercamiento a dos paradigmas de la tradición judeo-cristiana de crítica legalista del Primer Testamento, a saber, la tradición abrahámica y la reflexividad legal mosaica.

Esta aproximación bíblica persigue el enriquecimiento y actualización de la conceptualización antropo-teológica de la persona, a la vez que una reflexión teológica sistemática acerca de la relación que se establece entre el ser humano y la ley y acerca del impacto de la 
lógica legalista sobre la persona. No obstante, habría que preguntarse por la pertinencia de una determinada lectura bíblico-teológica a la hora de asumir una crítica teórica a los impactos negativos de las leyes económicas, políticas, culturales, religiosas, antes aludidas, sobre la vida del ser humano. En otras palabras, preguntarse si es relevante recuperar la centralidad de la categoría persona frente a la totalización y absolutización de la ley, en términos bíblico-teológicos.

Habría que tener presente que el cristianismo es una fuente teológica y cultural fundante de la sociedad occidental y, por tanto, que el abordaje aquí sugerido se ancla a las propias raíces religiosas de la cultura occidental judeo-greco-cristiana ${ }^{3}$. Aun cuando su base de fundamentación no se agote en los textos canónicos, sino que constantemente se está reconstruyendo y reformulando en el cristianismo histórico, estos textos resultan fundantes de la tradición cristiana, y por ende, de la occidental. En la síntesis ofrecida por Duquoc: «el Evangelio forma parte de la cultura occidental $»^{4}$, dado que los propios textos fundantes del cristianismo son aquellos que igualmente fundan la civilización y cultura occidentales, consignando categorías y conceptos que resultan centrales para el pensamiento de esta sociedad.

Esta fuente que es el cristianismo tampoco es unívoca, en la medida en que a su interior se expresan diferentes tradiciones, vertientes, expresiones y corrientes teológicas e interpretativas de los propios textos canónicos, muchas veces en abierta tensión y conflicto.

En lo que aquí nos ocupa, la discusión humanista de la relación entre la persona y la ley, a lo largo de la historia de la cristiandad se ha mostrado una vertiente de cristianismo vinculado al poder que ha

3 La tradición cristiana no es solamente génesis fundante y constituyente de la sociedad occidental sino que continúa siendo su denominador común, al margen de la propia secularización y desacralización de esta de cultura occidental. Cf. C. Vidal, El legado del cristianismo en la cultura occidental (Madrid: Espasa Calpe, 2000); E. Schillebeeckx, Cristo y los cristianos (Madrid: Cristiandad, 1982), entre otros.

4 Ch. Duquoc, Cristología. Ensayo dogmático sobre Jesús de Nazaret el Mesías (Salamanca: Sígueme, 1992), 213. 
contribuido, en cierta medida, a la negación de la persona y a la desvirtuación de los contenidos materiales del concepto persona, cuando afirma y sostiene la ley por encima del ser humano concreto, y así mismo, cuando pretende autoimponerse normativamente (cruzadas, conquista y colonización, son solo algunos ejemplos dramáticos). Es decir, cuando no es capaz de discernir la ley, sopesarla, relativizarla e intervenirla a favor del ser humano, la tradición cristiana participa intencional o inintencionalmente del sacrificio de una parte de la humanidad a favor de una ley -cualquier ley- que se absolutiza e impone por encima de la persona ${ }^{5}$.

Sin embargo, este mismo cristianismo, en su expresión y vertiente más auténtica, se encuentra anclado a una tradición cristiana crítico-humanista de vindicación de la persona y de relativización de la ley a favor de la persona, presente desde los orígenes mismos del judeocristianismo. Se trata de una vertiente teológica mucho más consciente del conflicto intrínseco en torno a la ley y de la necesaria afirmación de criterios de discernimiento del ser humano frente a ella. Esta tradición cristiana humanista atraviesa toda la historia de la cristiandad: supera las clásicas diferenciaciones entre cristianismos conservadores y progresistas, cristianismos de derecha o de izquierda, cristianismos dogmáticos o liberacionistas, pues cuando se trata de la afirmación de la vida humana generalmente se produce una vinculación entre las tradiciones más conservadoras y las corrientes de teología crítica, en el sentido de afirmación de la persona y la vida humana por encima de las mediaciones institucionales que producen o potencian la muerte ${ }^{6}$.

Cf. el tema del repensar y cuestionar un tipo de tradición cristiana vinculada al poder que produce y reproduce una «lógica sacrificial» en F. Hinkelammert, El grito del sujeto. Del teatro-mundo del evangelio de Juan al perro-mundo de la globalización (San José: DEI, 1998), 332-351.

6 Es importante afirmar que el conservadurismo cristiano no ha sido un pensamiento de afirmación absoluta de la ley, lo cual genera una tensión entre este pensamiento y las posturas cínicas actuales de totalización y absolutización de la ley por encima de las personas: «Cuando la contraposición es entre ley absoluta del mercado y sobrevivencia humana, no corren los viejos esquemas de izquierda y derecha, ni de conservadores y progresistas. El conservadurismo, que no es el neoconservadurismo, el conservadurismo cristiano, católico y protestante tiene una posición crítica frente a la ley. No es de afirmación absoluta de la ley». Duque y Gutiérrez, Eds., Itinerarios de la razón crítica (San José: DEI, 2001), 36 
Esta tradición cristiana humanista resulta susceptible de ser explorada y recuperada a partir de la lectura e interpretación de algunos textos bíblicos veterotestamentarios fundantes del cristianismo, desde los cuales es posible perfilar un núcleo de análisis de la relación entre persona y ley. Tal aproximación a la lógica de la ley en relación con la persona, adquiere además relevancia en el marco de los estudios judíos veterotestamentarios, tomando en cuenta que la exégesis cristiana del Primer Testamento «ha hecho hincapié en la fe, la moralidad, la espiritualidad y los valores universales (...), mientras que los detalles de leyes, rituales y asuntos particulares israelitas podían quedar incluidos en el capítulo de las 'obras', y no en el de la 'fe'»'. Estos temas centrales del judaísmo, como la ley, han tenido una importancia más limitada en la tradición bíblica, en tanto que fueron superados en alguna medida por acontecimientos e ideas teológicas centradas en la figura de Jesús. En lo que sigue, se pretende explorar este núcleo crítico a partir de la lectura hermenético-filosófica de algunos textos bíblicos asumida por Franz Hinkelammert, la cual será interpretada y dialogada aquí en clave bíblico-teológica-humanista.

\section{El "no al matar" abrahámico y la cuestión de la fe.}

En el análisis sobre los mitos fundantes ${ }^{8}$ de la sociedad occidental que aporta Franz Hinkelammert, el mito hebreo del patriarca Abraham resulta el constitutivo, por excelencia, de las relaciones de poder y

7 J. Barton, Ed., La interpretación bíblica hoy (Santander: Sal Terrae, 2001), 173.

8 Este análisis aparece principalmente en F. Hinkelammert, La fe de Abraham y el Edipo occidental (San José: DEI, 1989), y Sacrificios humanos y sociedad occidental: Lucifer y la bestia (San José: DEI, 1991), obras en las que el autor reconstruye algunos mitos de las tradiciones judía, griega y cristiana, que fundan una sociedad occidental pretendidamente secularizada y por tanto, amítica o postmítica. Como fuente teológica y cultural, el cristianismo aporta algunos mitos que «fundan la conciencia social y formulan el espacio dentro del cual todas las relaciones sociales -en especial las relaciones de dominación-se forman. Este espacio mítico no es necesariamente consciente, aunque el mito fundante lo exprese de alguna manera». F. Hinkelammert, La fe de Abraham y el Edipo occidental, op. cit., 15. Para el autor, estos mitos que subyacen en las concepciones sociales resultan un componente esencial de la razón y acción humanas, aun cuando no sean necesariamente conscientes. 


\section{dominación del occidente cristiano ${ }^{9}$. Si bien las sociedades occiden- tales cristianas surgen en la Edad Media, estas tienen una historia anclada en sociedades anteriores y en sus propios mitos fundantes.}

Hay un mito central alrededor del cual el cristianismo se ha desarrollado en términos sacrificiales, y en consecuencia, en términos de la afirmación irrestricta del poder. Se trata del mito del sacrificio de Isaac por su padre Abraham. En la preparación y argumentación del cristianismo sacrificial ha jugado un papel clave, y lo sigue jugando ${ }^{10}$.

El mito de Abraham, ampliamente abordado e interpretado tanto por las tradiciones teológicas judías como cristianas, describe de manera privilegiada la relación entre la persona y la ley, y finalmente entre la vida y la muerte. Tal es la tensión que expresa el texto, en términos de una muerte sacrificial o asesinato que no es llevado a cabo y, por tanto, resulta en la posibilidad para la víctima, de seguir viviendo. La historia se recoge en Génesis 22, 1-1411 y relata el momento en que Dios pide a Abraham llevar a su único hijo, Isaac, al monte de Moriah ${ }^{12}$, para ser sacrificado. Abraham asume el reto de la prueba y se dirige, brasero, cuchillo y leña en mano, junto a Isaac, al lugar indicado. Una vez allí, ata a Isaac a un altar y se dispone a degollarlo. En ese momento aparece el ángel de Yahweh que le pide

Al tratar la historia de Abraham como mito, no se le está negando su historicidad. De hecho, podría tratarse de un mito surgido a partir de un hecho histórico o resultar un relato alegórico que responde y explica la realidad de una sociedad o cultura. En cualquier caso, los mitos resultan una «verdad histórica» en la medida en que condicionan o expresan ciertas formas de vida y pensamiento. Desde el punto de vista histórico, es real el mito en tanto sucede en una comunidad humana o contribuye a la comprensión de sus estructuras sociales y culturales. Se trata de mitos «históricamente reales» que, por lo mismo, resultan reales. Cf. Ferrater Mora Diccionario de Filosofía (Barcelona: Ariel, 1998), 2422ss.

10 F. Hinkelammert, La fe de Abraham y el Edipo occidental, op. cit., 345.

11 Aun cuando el relato tradicionalmente se extiende hasta el v. 19, es conveniente reducir este análisis a aquella perícopa considerada como el material narrativo más antiguo, esto es, vv. 1-14. Con el detalle de la etiología (nombre de la localidad, perdida en el transcurso de la historia de la tradición y la explicación de la misma) en el v. 14, terminaba anteriormente la narración. Los vv. 15-19 resultan una adición posterior, que no tiene una función dentro de la narración primigenia misma. Cf. C. Westermann, El Antiguo Testamento y Jesucristo (Madrid: Fax, 1985), 355. Para G. von Rad, el texto es un claro ejemplo de conexión entre antiguos materiales narrativos (vv. 1-14) con la promesa de los patriarcas, lo cual ocurre precisamente en el inserto v. 15. A partir de este enlace se cambia radicalmente el significado de la narración primitiva que trataba del rescate de un niño dedicado al sacrificio, con la inmolación de un animal, en una antigua tradición cultual. De tal modo, el contenido del antiguo significado ha llegado a ser completamente ajeno al texto actual. Cf. G. von Rad, Teología del Antiguo Testamento, Vol I (Salamanca: Sígueme, 1993), 221.

12 El lugar exacto que emplea el relato es el "país de Moria», del que no se conoce absolutamente nada. La versión siríaca en su lugar dice: «de los amorreos». Cf. Ibíd., 295. 
no sacrificar a su hijo, a lo que responde Abraham afirmativamente, liberando a la víctima e inmolando, en su lugar, a un carnero ${ }^{13}$.

El texto forma parte del conjunto narrativo elohísta ${ }^{14}$. Pero a pesar de que la obra elohísta se ha constituido como una fuente propia, resulta imposible su disección y reconstrucción en su forma primitiva -búsqueda de la saga original-, aún en la pequeña perícopa que nos ocupa, producto de su entrelazamiento con la fuente yahwista. Esta limitante de reconstrucción «originaria», afirmada por el hecho de que es un relato que necesariamente tuvo que recorrer varias etapas de elaboración, durante las cuales los materiales básicos estuvieron en constante transformación hasta su formulación definitiva ${ }^{15}$, reafirma la imposibilidad de deducir un único sentido del texto. En efecto, en él subyacen niveles distintos de sentido y una multiplicidad de interpretaciones posibles. En esta línea, respecto a Gn. 22, comenta von Rad:

13 Reproducimos Gn. 22 para una mayor comprensión: «(1) Después de estas cosas sucedió que Dios tentó a Abraham y le dijo: "iAbraham, Abraham!" Él respondió: "Heme aquí". (2) Díjole: "Toma a tu hijo, a tu único, al que amas, Isaac, vete al país de Moria y ofrécele allí en holocausto en uno de los montes, el que yo te diga". (3) Levantóse, pues, Abraham de madrugada, aparejó su asno y tomó consigo a dos mozos y a su hijo Isaac. Partió la leña del holocausto y se puso en marcha hacia el lugar que le había dicho Dios. (4) Al tercer día levantó Abraham los ojos y vio el lugar desde lejos. (5) Entonces dijo Abraham a sus mozos: "Quedaos aquí con el asno. Yo y el muchacho iremos hasta allí, haremos adoración y volveremos donde vosotros". (6) Tomó Abraham la leña del holocausto, la cargó sobre su hijo Isaac, tomó en su mano el fuego y el cuchillo, y se fueron los dos juntos. (7) Dijo Isaac a su padre Abraham: "iPadre!" Respondió: "¿Qué hay, hijo?" -"Aquí está el fuego y la leña, pero ¿̇dónde está el cordero para el holocausto?" (8) Dijo Abraham: "Dios proveerá el cordero para el holocausto, hijo mío". Y siguieron andando los dos juntos. (9) Llegados al lugar que le había dicho Dios, construyó allí Abraham el altar, y dispuso la leña; luego ató a Isaac, su hijo, y le puso sobre el ara, encima de la leña. (10) Alargó Abraham la mano y tomó el cuchillo para inmolar a su hijo. (11) Entonces le llamó el Ángel de Yahvé desde los cielos diciendo: "iAbraham, Abraham!" El dijo: "Heme aquí" (12) Dijo el Ángel: "No alargues tu mano contra el niño, ni le haga nada, que ahora ya sé que tú eres temeroso de Dios, ya que no me has negado tu hijo, tu único". (13) Levantó Abraham los ojos, miró y vio un carnero trabado en el zarzal por los cuernos. Fue Abraham, tomó el carnero, y lo sacrificó en holocausto en lugar de su hijo. (14) Abraham llamó a aquel lugar "Yahvé provee", de donde se dice hoy en día: "En el monte Yahvé provee"». Todos los textos bíblicos son tomadas de la Biblia de Jerusalén (Bilbao: Desclée de Brouwer, 1978).

14 A partir de las investigaciones de la escuela histórico-crítica y su hipótesis documentaria, se afirma la obra elohísta como una de las fuentes narrativas más antiguas, fechada entre el 850 y el 750 a.C., unos dos siglos después del yahwista (entre los siglos x y XI a.C.). El Eloísta está compuesto por narraciones profundamente introyectadas en la conciencia religiosa judía, y ligadas a la antigua tradición y el credo judíos. Cf. Ibíd., 99. 
(...) hemos de renunciar de antemano a deducir una idea básica que constituya el sentido de todo él. Existen muchos estratos de significado (...). Una historia como ésta está básicamente abierta a la interpretación, y quien la narra no piensa en andar poniendo trabas a los pensamientos que ella suscite en el lector, sean de la índole que fueren; está contando un hecho, no enunciando una doctrina ${ }^{16}$.

Una historia que reclama interpretaciones, un texto «abierto a la interpretación». No solo por la natural apertura de la narración a sentidos ocultos, apenas sugeridos y misteriosos (como la intervención inicial y final de Dios), o por el escaso lugar que se da en un texto tan intenso a las relaciones interpersonales. O incluso, por la ausencia en el propio relato de cuestiones aclaratorias desde el punto de vista histórico - ¿̇de dónde habían partido?, żqué ritos podrían celebrarse en este santuario, suponiendo que hubiera existido?--, susceptibles de ser aclaradas por vías extratextuales: historia y sociología de las religiones, liturgia judía, etc. Más allá de estas cuestiones particulares que amplían el margen de relecturas posibles, este relato ha exigido, en la historia de la exégesis y la hermenéutica bíblicas, una continua y profunda reflexión de sus tópicos teológicos más relevantes. A pesar de la multiplicidad de contenidos que están implícitos en el texto, es evidente que temas como la prueba o tentación, la fe-obediencia, el sacrificio, las promesas patriarcales, han sido privilegiados por los exégetas en la interpretación de esta perícopa, dada su relevancia como claves bíblico-teológicas.

Respondiendo a nuestro interés por lo propiamente hermenéutico, queremos mostrar la interpretación hinkelammertiana sobre el mito de Abraham a partir de tres aspectos teológicos, a saber, la prueba, la fe y el sacrificio. No se trata de una única lectura posible, sino únicamente una interpretación legítima si aceptamos que legítima es toda aquella «lectura nueva, una 'creación' que no ignora ni las aristas del texto, ni la comunidad de cultura y de fe a la que pertenece [el intérprete] y a la cual quiere servir» ${ }^{17}$.

17 G. Rouiller y P. Ricoeur, Dir., Exégesis. Problemas de método y ejercicios de lectura. Génesis 22 y Lucas 15 (Buenos Aires: La Aurora, 1978), 337. 


\section{1 ¿Prueba o inercia legalista?}

El texto de Gn. 22 de entrada nos informa su contenido: se trata de una prueba que Dios pone a Abraham. Es único en tanto inicia con este encabezamiento o informe del tema (v. 1), donde se sintetiza el evento que sigue a continuación con la expresión: Dios prueba a Abraham. Una declaración que aparece en el nivel discursivo del narrador, quien evidentemente conoce y domina las historias de Abraham e Isaac (cf. «después de estos acontecimientos», v.1). El uso del verbo nissah (prueba/tentación) por parte de este narrador matiza y enmarca toda la narración que prosigue. Se trata de una prueba en la que se compromete y evalúa aquello que debe ser probado; un proceso de clarificación, algo que sucede con el fin de evacuar dudas o confirmar una idea o actitud, y que ha de darse en el propio decursar narrativo ${ }^{18}$. Sin embargo, inmediatamente aparece el problema del tipo de prueba de que se trata. De acuerdo a como se interprete el texto, se interpreta la prueba, y a la inversa, de acuerdo a como se interprete la prueba, se expondrá una determinada hermenéutica del texto. Aquello que Dios prueba en Abraham pudiera ser la obediencia o la libertad, y en este sentido, puede probarse la obediencia a una ley o tradición, como también probarse la libertad ante las mismas leyes o tradiciones supeditándolas al respeto a la vida, en este caso, la vida de Isaac.

La interpretación más «tradicional» del texto tiene una estructura que básicamente se puede resumir de la siguiente manera: Dios prueba la fe de Abraham en su obediencia y disposición a sacrificar lo más preciado de sí, su hijo Isaac. El evento-prueba implica una acción extraordinaria, fuera de lo común. Si Abraham está dispuesto a realizar esa acción extraordinaria de matar a su hijo primogénito,

18 En consonancia con ello, el evento implica: a) la enunciación de la prueba como punto de partida; b) el sometimiento del destinatario de la misma a una situación límite provocada, como proceso; y c) la evaluación o pronunciamiento de juicio, como punto de llegada o resultado. En este sentido, el texto de Gn. 22 sigue una línea de pensamiento bien definida: (a) Abraham recibe la tarea para la prueba en la exigencia del sacrificio de su hijo Isaac; (b) se somete y acepta la prueba; y (c) es evaluado en su respuesta a la exigencia sacrificial. 
ratificando su fe con la obediencia al mandato sacrificial de Dios, cumpliría la prueba y Dios le premiaría como Padre de una nueva nación.

En la lectura del texto de Gn. 22 que hace Franz Hinkelammert esta interpretación tradicional tendría dos dificultades fundamentales. La primera, que al abstraer del contexto histórico, el texto presenta como prueba algo que no tiene ese carácter extraordinario, en tanto responde a una costumbre de la época o ley consuetudinaria del sacrificio del primogénito. La segunda, y más importante, que se trata de una prueba de obediencia ciega e irracional y no una prueba de libertad y amor. Para el teólogo alemán, Abraham se enfrenta como cualquier persona de su tiempo, a una demanda de su cultura y del aparato de Estado. El Dios de la prueba es, por tanto, un Dios genérico, «cualquier Dios» ${ }^{19}$, el Dios de la religión del Estado o de las tradiciones de los patriarcas, que pide a los padres la muerte de sus primogénitos, dentro de una ley comúnmente aceptada:

Según el texto, Abraham sale a sacrificar a su hijo, porque Dios le exige este sacrificio. Se trata de un sacrificio del primogénito, que es ley general en el tiempo en el cual vive Abraham. Es ley vigente en toda esa cultura. Por tanto, es considerada ley de Dios. No puede sorprender, por tanto, que según el texto, Dios pida a Abraham el sacrificio de su hijo. Lo pide a todos los padres dentro de una ley generalmente aceptada. Tampoco puede sorprender que Abraham esté dispuesto a efectuar el sacrificio. Todos los padres de su cultura lo hacen y todos están dispuestos a ello ${ }^{20}$.

$\mathrm{Al}$ inicio de esta exposición, hemos ubicado la fecha de este texto elohísta en el siglo VIII a.C. Ello nos permite relacionar tal datación con aquel contexto histórico donde se desarrolla la narración. Se trata de un período en el que ocurrían sacrificios de niños ${ }^{21}$. Era una práctica común que era llevada a cabo por el Estado y los reyes, con el propósito de: 1) superar las crisis y dificultades sociales provocadas por sequías, epidemias, etc, aplacando la divinidad con el sacrificio

Cf. el nombre Elohim en los vv. 1.4.8s. Resulta válido sospechar que pudiera tratarse de un dios cananeo, máxime si se considera Gn. 22 como una tradición local muy antigua, preyahwista F. Hinkelammert, El grito del sujeto, op. cit., 17.

Cf. 2 R. 16.3s y 17.17. Véase también la indignación contra esta práctica común en 2 R. 3.27 y Lev. 20.1-5. 
de niños; y 2) estabilizar las instituciones estatales (ejército, templo, muros de la ciudad-estado) ${ }^{22}$.

El sacrificio respondía a las leyes vigentes impuestas por el Estado, y en tanto tal, consideradas «leyes de Dios». Al tomar a Isaac y salir de camino a Moriah, Abraham no hace más que cumplir inercialmente la legalidad vigente en su época; no hace nada extraordinario, como no es tampoco extraordinaria la exigencia hecha por Dios.

La interpretación tradicional de la historia presupone que esta exigencia de Dios a Abraham, sea algo extraordinario. Si no lo fuera, no sería prueba. En el tiempo histórico de los Macabeos (...), una prueba así habría sido realmente algo extraordinario. En este tiempo, jamás un padre sacrificaba a su hijo a Yavéh o a ningún otro Dios. En el mundo oriental ya no existían sacrificios humanos de tipo religioso. Ni los judíos, ni los griegos o romanos, los seguían sosteniendo. Por lo tanto, una exigencia de tal sacrificio habría sido una prueba extraordinaria. (...) No obstante, en el momento histórico en el cual se escribe la historia de este sacrificio (alrededor del siglo 8 a.C.), la situación es completamente diferente. Mucho más todavía en los tiempos anteriores, en los cuales esta historia debe haber sido trasmitida oralmente. En este tiempo el sacrificio del hijo primogénito es la regla, no la excepción. Esto se hace por razones mágicas, para asegurarse la gracia de los dioses, especialmente frente a una batalla. Sacrificar al hijo primogénito es la tentación del hombre de autoridad frente a un juicio imprevisible de Dios, para inclinar la voluntad de este Dios en favor suyo ${ }^{23}$.

Al estar dispuesto Abraham a matar a su hijo, está cumpliendo con la tradición cultural y legal de su época, y obedeciendo sin ningún discernimiento el mandato de Dios. Se trata entonces de un Abraham que sigue inercialmente una ley de su tiempo y por tanto, no hay nada extraordinario ni en la prueba, ni en su comportamiento. $\mathrm{Al}$ tomar en cuenta el texto en su contexto, el texto pierde toda su fuerza e intención explicativa, y no se entendería por qué Abraham merece ser llamado el fundador y padre de una nación, cuando inten- 
ta llevar a cabo lo que todo padre de su comunidad hace ${ }^{24}$. Frente a un Dios que exige el cumplimiento de la ley, desaparece el elemento de sorpresa por el carácter y magnitud de la petición misma. Que una prueba de esta índole sea planteada en estos términos deja de sorprendernos, como no nos sorprende tampoco la actuación de un Abraham inhumano, dispuesto a asesinar a su hijo ${ }^{25}$. Se muestra un Abraham que responde a las demandas de la «ley de Dios» vigente en su medio. Pero lo sorprendente del texto, desde la óptica del contexto socio-histórico, es que el sacrificio no se lleve a cabo.

La sorpresa es que ahora aparezca el Ángel de Dios, que pide a Abraham no sacrificar a su hijo. Pide violar la ley, pide una transgresión de la ley de Dios. Pide un acto difícil, que va a confrontar a Abraham con toda su cultura y con toda la sociedad en la cual vive. Pide una ruptura con toda la ley vigente de su tiempo, y por tanto una lucha. Además, como consecuencia va a tener que cambiar su lugar de residencia, que él toma entonces en Bersebá. Probablemente hay persecución de Abraham, por haberse opuesto a la ley ${ }^{26}$.

Siguiendo el texto, se presenta ahora un mensajero o enviado del Dios Yahweh, o finalmente Dios mismo, que pide detener el sacrifi$\mathrm{Cio}^{27}$. Y es aquí cuando se inicia la verdadera prueba. Hasta entonces Abraham no se había sometido a ninguna petición extraordinaria y sorprendente, a ninguna situación límite; había seguido inercialmente a la ley de Dios y al sentido común de su tiempo. Pero ahora Abraham, por vez primera, tiene que enfrentar la prueba de violar la ley de Dios, aquello que fue prescrito como norma para preservar

Para Hinkelammert, la interpretación tradicional que considera como extraordinaria la disposición de Abraham al sacrificio de su hijo, encuentra fuerza en las sociedades posteriores y hasta el presente, en la medida en que son sociedades en las que este tipo de sacrificios han sido completamente erradicados. A los ojos de un creyente contemporáneo un sacrificio de ese tipo resulta algo completamente extraordinario. Sin embargo, tal sensibilidad ahistórica y extemporánea invertiría todo el sentido del texto.

25 Cf. M. Schwantes, La familia de Sara y Abraham, op. cit., 28ss.

26 F. Hinkelammert, La fe de Abraham y el Edipo occidental, op. cit., 17. Cursivas de la autora.

27 Schwantes anota la importancia de que la «desactivación» del sacrificio deba ser expresada a nivel teológico: «La orden, la exigencia de que sean sacrificados niños, viene de la divinidad, sea ella una de las divinidades del mundo circundante (II R. 3.27), sea ella del propio Dios de Israel (Ex. 22.29). Este tipo de sacrificio es una exigencia divina (...) Para desarticular, desactivar, deshacer esta exigencia, para establecer una nueva práctica, es necesaria una contra-orden divina, una nueva palabra de Dios. La solución, por tanto, está en el plano teológico». M. Schwantes, «No extiendas tu mano contra el niño. Reflexiones sobre Génesis 21 y 22», RIBLA 10 (1991): 42. 
el Estado y sus instituciones. Es en este momento, y no antes, que verdaderamente Abraham es confrontado: podrá salir airoso o fracasar la prueba. Abraham, como hombre de su época avanza hasta el amarramiento de Isaac en el altar, pero la prueba va más allá. Trata de la decisión sobre la vida y la muerte del hijo. Ahora Abraham se enfrenta a esta tensión vida-muerte y de su respuesta depende el grado de superación de la prueba.

En el criterio de Hinkelammert, la prueba realmente crucial y que exige de Abraham un comportamiento extraordinario, es una prueba que demanda de este un discernimiento de la situación en la que se encuentra, a partir del mandato inicial de matar a su hijo. Pero igualmente, le demanda una toma de decisión que lo puede enfrentar, y de hecho lo enfrenta, a su tradición, a su cultura, a la ley de su comunidad y al propio Dios que le ha dado el mandato inicial. Se trata, entonces sí, de una prueba realmente extraordinaria. En ella Abraham, desde su fe en Dios y mediante un acto de libertad, se ve obligado a discernir la ley vigente en su tiempo, sus tradiciones culturales y religiosas; en otras palabras, a discernir los propios dioses de su época.

Abraham debe discernir entre la palabra de Dios que consagra el sacrificio del primogénito y esta nueva palabra de Dios que pide no sacrificar. Pudiera tratarse de dos dioses distintos, como ha sido nuestro criterio expreso, o de palabras distintas del mismo Dios. Pero, en cualquiera de los dos casos, tiene que efectuar un discernimiento. Se trata de un discernimiento entre el Dios de la promesa y el Dios de la ley. El primero, rompe con la ley, incluso con la ley natural, la biológica. Según esta ley, Abraham y Sara no estaban en la edad reproductiva o edad fértil en la que se puede procrear. Sin embargo, en consonancia con la promesa de Dios, ellos engendran a su hijo Isaac. Se trata de un Dios que rompe con la ley biológica para crear la vida humana, para crear la persona de Isaac. Un Dios para quien es vital que el ser humano viva. En consonancia con ello, el Dios de la Promesa aparece de nuevo y le pide romper con la ley que exige el sacrificio del primogénito, de la vida. Él se manifiesta en la vida. Este Dios de la promesa se confronta con un 
Dios de la ley que privilegia el cumplimiento de la ley por encima de la vida humana; para este tipo de Dios, si las leyes vigentes demandan el sacrificio de un niño, entonces éste debe morir.

En el marco de la tensión vida-muerte, y según la interpretación tradicional de Gn. 22, Abraham supera la prueba en la medida en que estuvo dispuesto a matar al hijo. Desde esta nueva perspectiva, la superación de la prueba consiste en negarse a matar al hijo. Es decir, en atreverse a desafiar las leyes y ordenanzas político-religiosas de su tiempo, no sacrificando a Isaac. Con ello, se invierte el propio sentido de la prueba, como prueba negativa:

En este caso, la prueba consiste en algo que había que rechazar para pasarla. Dios exige el sacrificio de Isaac como prueba. Si Abraham lo sacrifica efectivamente, pierde la prueba y resulta un hombre sin fe. Un hombre que hace lo que todos hacen, que cumple la ley que exige este sacrificio. Sería un hombre de su tiempo. Al renunciar al sacrificio y rechazarlo, él se transforma en un hombre de fe frente a la ley vigente. Al hacer lo que nadie hace, es el hombre de la fe para todos sus descendientes, de todos los tiempos. Aparece el Dios viviente de los vivos, al cual se entrega al hijo por el acto de no sacrificarlo ${ }^{28}$.

Este sentido hermenéutico redimensiona el eje temático de la propia promesa patriarcal, pues se podría arriesgar a pensar que la prueba era para saber si era capaz de ser Padre de Isaac, el Padre de la promesa, el Padre de la vida de toda una nación. Él supera la prueba, dando como resultado rechazar el sacrificio de su hijo.

\subsection{Conversión, fe y libertad}

Abraham sale airoso de la prueba, negándose a matar, pero el sentido profundo de este negarse a la muerte recae en las razones por las cuales Abraham no mata a Isaac. Lo que Hinkelammert interpreta como sigue:

Abraham se liberó frente a la ley, se dio cuenta que la ley le exigía un asesinato y descubre al Dios, cuya ley es ley para la vida. Abraham se convierte y se libera. No mata, porque se dio cuenta que la libertad está en el No al matar. Por tanto, su fe está en eso: en no estar dispuesto a matar, ni a su 
hijo, ni a los otros. Abraham, libre por ley, se liberó para ser un Abraham

libre frente a la ley, siendo la raíz de su libertad el rechazo a matar ${ }^{29}$.

Se pudiera identificar en el texto hinkelammertiano una triada teológica que fundamenta la lógica no-sacrificial: Abraham no mata a su hijo porque «se da cuenta que la ley exige un asesinato y descubre a Dios» (conversión), «no está dispuesto a matar, ni a su hijo, ni a los otros» (fe) y «se libera frente a la ley» (liberación). De forma esquemática, podemos visualizar estas razones como actos constitutivos del proceso de superación de la prueba, lo que abordaremos más detalladamente.

Primero, se trata de un acto de conversión como reconocimiento. Aquel que tiene en sus manos la autoridad -paterna, religiosa, política- para consumar un asesinato; aquel que tiene todo el poder y potestad de ejecutar la muerte-como demanda inercial de la ley de una época-, reconoce y se sensibiliza ante una nueva opción liberadora. La conversión aparece como la apertura consciente a la nueva posibilidad que se le ofrece ${ }^{30}$. Un abrirse a la sospecha respecto de aquello que ha creído correcto y naturalmente dado, y sobre las razones que subyacen a esta creencia. Abraham se abre al cuestionamiento y descubre que «la ley puede ser válida solamente en cuanto respeta la vida; no será válida, legítima, si exige la muerte» ${ }^{31}$ y solo así es capaz de escuchar la voz de Dios y reconocer el horizonte de vida y negación de la muerte, dado por Dios.

Aparece, en la formulación de Hinkelammert, otro elemento más de reflexión en torno a la conversión como acto de reconocimiento. El descubrimiento del Dios de la vida y su conversión a Él, está mediado por el reconocimiento del hijo ${ }^{32}$ :

29 F. Hinkelammert, El grito del sujeto, op. cit., 51s.

30 Siguiendo esta idea, «la conversión acompaña e impulsa lo que puede ser considerado como un segundo y progresivo nacimiento, por el que, en disposición libre, consciente y paulatina de nosotros mismos, vamos profundizando más de lo que somos, eliminando lo inauténtico y asumiendo lo que podemos llegar a ser: nuestra auténtica existencia e identidad humanas». C. Floristán y J. J. Tamayo Eds., Conceptos fundamentales del cristianismo (Madrid: Trota, 1993), 243.

31 J. Duque y G. Gutierrez, Itinerarios de la razón crítica, op. cit., 145.

32 Se trata de una presencia viva de Dios en el encuentro con el otro y su reconocimiento. En otras palabras, Dios se hace presente cuando hay relación entre sujetos y es negado en el desconocimiento de las relaciones intersubjetivas. 
El mito deja entender que Isaac cuestiona el sacrificio y se resiste. Se convierte al asumir su propia dignidad, lo que no es compatible con la aceptación de ser sacrificado. Pero Abraham tiene todo el poder sobre él y lo amarra en el altar, para matarlo. Pero en ese momento se convierte él mismo también. Ve el rostro de Isaac y le surge la fe: esta fe se confirma al no matarlo. La conversión es doble y complementaria. Isaac se convierte, al resistir ser sacrificado. Abraham se convierte, al reconocer a Isaac como ser humano vivo, que no vive para morir. Renuncia a ser sacrificador. Por tanto, viola la ley que prescribe el sacrificio del hijo primogénito. Convertidos los dos, pueden bajar juntos del cerro. La conversión no es posible, si no se convierte el dominador también. La conversión es una relación de reconocimiento mutuo, aunque conflictivo ${ }^{33}$.

Hinkelammert adjudica la invisibilización de la conversión de Isaac dentro del texto de Gn. 22, al hecho de ser contado por los patriarcas, dentro de una sociedad patriarcal y adultocéntrica. Se habla de Abraham que es el patriarca, pero a la par, para ser sacrificado como víctima, está Isaac.

Segundo, se trata de un acto de fe como afirmación de la vida. Ya hemos precisado que para el autor, la fe de Abraham radica en no haberlo matado. Sin embargo, la interpretación teológica tradicional ha entendido la fe de Abraham como su disposición para realizar el sacrificio, matando a Isaac: Abraham demostraría tener fe y ser obediente en tanto capaz de cometer asesinato. Como premio a su «entrega»y «buena voluntad», Dios le recompensa con salvarle la vida del hijo. «La interpretación dominante (...) es que él estaba dispuesto a matarlo, no obstante Dios intervino porque la disposición a matar a su hijo era prueba suficiente de su fe. La buena intención de matarlo era suficiente, Dios lo redimió de consumarla». ${ }^{34}$

Según Hinkelammert, se trata de una inversión de la historia abrahámica en un sentido sacrificial, basada en gran medida en el

33 Hinkelammert ahonda en la inversión de la relación de poder que tipifican Isaac y Abraham: «También el dominador tiene que convertirse. Y eso es lo interesante en la figura de Abraham. El que se convierte es el Señor. Isaac es el perseguido, y Abraham el perseguidor. Y es Abraham el que se convierte porque Isaac ya está convertido, y además no puede hacer nada. Pero si Abraham no se convierte, Isaac está perdido. Y Abraham se convierte. Es decir, la conversión necesaria implica al dominador». Ibíd., 37.

F. Hinkelammert, El grito del sujeto, op. cit., 51. 
sentido atribuido a Gn. 22.12: «Dijo el Ángel: No alargues tu mano contra el niño, ni le hagas nada, que ahora ya sé que tú eres temeroso de Dios, ya que no me has negado tu hijo, tu único» ${ }^{35}$. Para el autor, esta frase bíblica supone que Abraham estuvo dispuesto a matar a su hijo, y en su opinión solo podría tratarse de un añadido posterior, una inserción que no corresponde al conjunto de la historia abrahámica auténtica. Sin embargo, el biblista Pablo Richard ${ }^{36}$ considera como interpretación perfectamente plausible del "no me has negado", la que le otorga el sentido de «no lo retuviste», «me lo diste», lo que equivale a «me lo has consagrado». Consagrar a Yahweh, en sentido estricto, se presenta en la historia de la salvación como un destinarlo a la vida, un conservarlo vivo. El propio Hinkelammert aborda la ambigüedad de la frase «no me has negado a tu hijo»:

\begin{abstract}
Al no matar a su hijo, Abraham no lo niega a Dios. Lo niega a la muerte. Pero el Dios de Abraham es el Dios de la vida. Entrega a Dios a su hijo precisamente al no matarlo. (...) Él rescata a su hijo para Dios al no matarlo (...) Aunque se incluyan estas inserciones, el texto de la historia del sacrificio de Isaac nunca afirma que la fe de Abraham haya estado en su disposición de matar a su hijo (...) Puede significar lo contrario: no has estado dispuesto a matarlo, porque al matarlo lo quitas a Dios. Dios, si es Dios de los vivos, lo querría vivo ${ }^{37}$.
\end{abstract}

La obediencia abrahámica radica, entonces, en no haber matado al hijo. Abraham obedece, justamente porque se niega a cumplir con la orden del sacrificio, afirmando con ello la vida de Isaac. En este mismo orden, varias pruebas bíblicas se superan por el hecho de no hacer lo que ellas exigen. En II Sam. 24,1-10, por ejemplo, Yahweh incita a David a hacer un censo en Israel, lo que efectivamente realiza el rey. Sin embargo, en este caso David no sale airoso de la prueba al haber cumplido con lo que Dios le exigía. Se trata de un tipo de prueba en el que se es obediente si se discierne y realiza el acto justo, aunque ello conlleve revertir el propio mandato de Dios.

\footnotetext{
35 Idéntica interpretación es extensible al inserto v. 16b. En el Nuevo Testamento está en consonancia con la interpretación de la fe abrahámica en la Carta a los Hebreos (cf. 11.17-19) y Santiago (cf. 2.2023), y contrapuesta a la postura paulina de una fe no sacrificial en conflicto con la ley.

36 En conversación personal con Pablo Richard.

37 F. Hinkelammert, La fe de Abraham y el edipo occidental, op. cit., 18s.
} 
En este acto de obediencia de discernimiento de la ley, se expresa igualmente la fe de Abraham. Una fe de conversión, no de simple adhesión y cumplimiento nomístico. Una fe que lo transforma en un creyente capaz de enfrentarse a la ley: «Abraham va al monte fiel a la ley y vuelve siendo creyente» ${ }^{38}$. Abraham había partido a Moriah con una «fe religiosa», expresada en su adhesión a la ley de Dios, sin cuestionar la «verdad» contenida en tal ley, y regresa siendo creyente del Dios viviente, del Dios de los vivos ${ }^{39}$.

Esta fe y renuncia abrahámica al sacrificio se hace extensible a toda la cultura y sociedad. Abraham no solo se niega a sacrificar a «su hijo», sino que con su negativa al sacrificio, abre la posibilidad para que todas las generaciones futuras también lo hagan. Así, el relato estaría mostrando el origen de la liberación de toda una cultura de una determinada ley sacrificial (ley del sacrificio del primogénito) y de ahí su alto contenido socio-cultural. De manera que, a partir de Abraham, la negación a la sacrificialidad de una ley que produce la muerte, está a la base de la propia conditio humana:

Lo que somos y lo que llegamos a ser al autorealizarnos, es ser sujetos vivientes. Este sujeto es el origen de la humanidad. En el inicio no está algún asesinato fundante -ni el asesinato de Freud, ni el chivo expiatorio de Girard-sino en el origen está un asesinato, que no se llevó a cabo. No asesinar es el origen de la humanidad. La humanidad no nace con Caín, quien mata a su hermano Abel. Nace con Abraham, quien no sacrificó a su hijo Isaac ${ }^{40}$.

Tercero, se trata de un acto de liberación como elección. Esta fe, como un rechazo al matar, es el fundamento mismo de la libertad

J. Duque y G. Gutiérrez, Itinerarios de la razón crítica, op. cit., 45. La fe del primer Abraham que sube al monte es una fe de cumplimiento ciego, que no toma en cuenta el criterio de la vida humana y por ello, no es capaz de discernir la ley. A propósito de esta "fe de ley», transcribo un grafitti que leí en una calle: «Fe sin el hombre es ley. La rebelión es justicia» (calle Benigno Malo, Cuenca, Ecuador).

39 A este tipo de fe abrahámica Juan L. Segundo le denomina «fe antropológica», considerándola anterior -no temporal, sino analíticamente- a toda clasificación religiosa: «Así presenta, en efecto, Pablo a Abraham (Rom. 4); es un hombre que, antes de ser clasificable religiosamente en una categoría determinada, cree ya en una especie de promesa que la historia de la liberación y humanización del ser humano parece dirigir a quienes luchan por ella. Creyó en «el Dios que da vida a los muertos y llama a ser a lo que no es» (Rom. 4.17)». J. L. Segundo, El caso Mateo. Los comienzos de una ética judeocristiana (Santander: Sal Terrae, 1994), 4.

40 F. Hinkelammert, El grito del sujeto, op. cit., 257. 
abrahámica. El Abraham que reconoce y se convierte a Dios, y expresa su fe en la negación a la muerte, se libera. Frente a la muerte, opta por la vida; frente a la esclavitud de la ley sacrificial, escoge la liberación del «no al matar»: se hace libre una vez que realiza un acto de libertad frente a la ley. La libertad es una tarea, un quehacer que se alcanza por el acto voluntario y consciente de hacerse libre, a través de la escogencia de la opción -única alternativa posible- por el Dios de la vida.

Lo que pide el Ángel, es hacerse libre y ponerse por encima de la ley. Abraham obedece. Por tanto, no obedece a ninguna norma y ninguna ley, sino que al obedecer se hace de una libertad, que lo pone a él por encima de la ley. Al ser libre, Abraham es soberano frente a la ley. Él juzga sobre la ley, y el Ángel le pide reivindicar esta libertad. A Abraham la obediencia lo hace libre, porque lo que se le pide, es ser libre. Esta libertad la afirma al no matar a su hijo y al enfrentar toda su sociedad, toda su cultura. (...) Abraham, libre por ley, se liberó para ser un Abraham libre frente a la ley, siendo la raíz de su libertad el rechazo a matar ${ }^{41}$.

La acción por la cual Abraham se libera, está en el negarse a matar. La manera que encuentra de liberarse es confrontándose a una ley para la muerte y optando por la vida de su hijo y la suya propia. Abraham se recupera a sí mismo y a Isaac a partir de la elección de un camino de libertad; no una libertad por ley, institucional -estatal, religiosa, patriarcal-, sino una libertad que interpela la ley sacrificial ${ }^{42}$.

\subsection{Sacrificialidad y muerte}

El sacrificio de Isaac resulta, sin duda, la temática más relevante e hilo conductor de la narración. De entrada se presenta como el móvil que encabeza la narración, y el contenido explícito de la

41 J. Duque y G. Gutiérrez, Itinerarios de la razón crítica, op. cit., 17.

42 Ibíd., 51. Interesante resulta la contraposición que hace Hinkelammert entre el Abraham que descubre su libertad y no mata a su hijo, con el mito griego narrado por Esquilo, de Agamenón matando a su hija Ifigenia: «La libertad griega (...) no fue más que la aceptación libre de leyes, aunque maten. La libertad frente a la ley, que somete ésta a las necesidades de la vida humana, solo fue concebible en la tradición de la fe de Abraham. Ni Grecia, ni Roma, descubrieron esa libertad humana originada en la fe de Abraham. (...) la recepción del cristianismo por el imperio -imperio romano primero, y tantos otros imperios después- sofocó esa gran libertad por medio de la tradición greco-romana, que nunca pudo ver más allá de la ley del poder y de la dominación como último límite de lo humanamente permitido» F. Hinkelammert, Cultura de la esperanza y sociedad sin exclusión (San José: DEI, 1995), 350. 
prueba: «ofrécelo (a Isaac) allí en sacrificio» (v. 2). Más tarde, este mandato sacrificial conforma el clímax de la narración, cuando la orden «ofrécelo en sacrificio» es trocada por un «no le hagas nada» (v. 12). Por el lugar que ocupa el tema del sacrificio dentro del texto no ha de sorprendernos que la interpretación cristiana tradicional presente la fe de Abraham como su disposición al sacrificio. Hinkelammert llama la atención sobre el énfasis que pone esta interpretación cristiana en la sacrificialidad de la narración, al contrastarla con la exégesis judía que visualiza el evento apenas como «amarramiento de Isaac»:

Hay una interpretación judía desde el tiempo de los macabeos (...) que normalmente habla del «amarramiento de Isaac». En esta línea va asimismo la interpretación en algunos lugares del mensaje cristiano, como en la carta de Santiago y en la carta a los Hebreos. En la tradición cristiana posterior es transformada y radicalizada en el «sacrificio» en el cual Abraham sacrifica a Isaac. Mientras la tradición judía enfatiza la figura del Isaac amarrado, en la tradición cristiana es enfatizado el Abraham sacrificador ${ }^{43}$.

En la tradición cristiana posterior, Abraham es presentado como el sacerdote fiel a la ley, que se dispone fríamente a sacrificar a la víctima, obviándose que esta víctima sea justamente el don recibido de parte de Dios, el hijo único y amado. Este Abraham-sacrificador contrasta con el Abraham-padre presente en el texto, que es capaz de cargar aquellos elementos que pudieran lastimar al hijo (fuego y cuchillo, cf. v. 6$)^{44}$. De esta actitud de padre atento, como de la expectativa no-sacrificial que expresa Abraham en el v. 5 («yo y el muchacho iremos hasta allí, haremos adoración y volveremos donde

43 F. Hinkelammert, El grito del sujeto, op. cit., 51. La exégesis judía aporta, además de su énfasis en el amarramiento de Isaac, otros elementos esclarecedores del mito, no menos relevantes. Así por ejemplo, se sugiere el mandato al sacrificio como una venganza de Agar, llevada a cabo por un falso profeta: «En el mito original, Agar se vengó de Sara atribuyendo un hambre a alguna acción de Abraham, pues en el Génesis se produce un hambre cuando él está ya casado con Sara, y otra en el relato de Isaac en Guerar, que parece haberse atribuido originalmente a Abraham. También sugiere que el sacrificio fue ordenado por un falso profeta, al que Agar sobornó para tal acción en venganza por haber sido desheredado Ismael». R. Graves y R. Patai, Los mitos hebreos (Madrid: Alianza, 2000), 156.

44 Milton Schwantes expresa estas actitudes abrahámicas como contrasentido: «Cuán extraña y contrastante es la actitud amorosa y amable del padre que lleva en sus propias manos el "fuego" y el "cuchillo" -esto es, las cosas peligrosas-, con la del padre hecho sacerdote que se pone a "matar" y a "inmolar" a su hijo. Juntas, estas dos actitudes no tienen sentido. No combinan. iO una, u otra!» M. Schwantes, «No extiendas tu mano contra el niño. Reflexiones sobre Génesis 21 y 22», op. cit., 41. 
vosotros»), pudiéramos deducir la no intencionalidad del acto de Abraham. Evidentemente, Abraham no desea hacer el sacrificio, no es su voluntad matar al hijo amado. Sin embargo, y más allá de su intención o voluntad, avanza en su actitud hasta el amarramiento de Isaac en el altar. Pero, no por ello tiene consciencia de estar haciendo el mal; de hecho, ni siquiera pasa a la historia como un padre desatento y brutal. Se somete a la ley del sacrificio, y por tanto, contribuye a la producción de su efecto sacrificial o de muerte, sin que medie una determinada intencionalidad sacrificial. En otras palabras, el Abraham sometido a la ley tiene «una actitud que asesina, con independencia de tener la intención de asesinar o no» ${ }^{45}$.

Para nuestro autor, la lógica sacrificial que está presente en el cumplimiento irrestricto de la ley trasciende las intencionalidades. El sacrificio no es asunto de bondades o maldades. Se puede ser un padre excelente y sacrificar al hijo, cuando se ha interiorizado profundamente una lógica de cumplimiento de la ley. No es una actitud perversa lo que le lleva a actuar como asesino; es el cumplir, honesta y consecuentemente con la ley vigente en su tiempo, en este caso, la ley del sacrificio. Y en este sentido, conviene ir más allá de una mera demonización del victimario, o incluso de una crítica a una determinada ley sacrificial (la ley de sacrificio del primogénito, por ejemplo) ${ }^{46}$.

Obviamente, es importante tomar en cuenta que el ámbito de la legalidad no se sitúa al margen de la intencionalidad de poder de individuos y grupos políticos y religiosos. Tal intencionalidad coyuntural de poder resulta sumamente relevante cuando está presente en una determinada aplicación y/o cumplimiento de las leyes vigentes. No obstante, la

\footnotetext{
45 F. Hinkelammert, El grito del sujeto, op. cit., 52.

46 Llama la atención que la mayoría de los exégetas, aun cuando comenten Gn. 22 desde una perspectiva liberadora, no toman en cuenta este aspecto. Plantean el sentido del texto en el marco del debate judío respecto a las leyes de sacrificio de niños o personas, y en tanto tal, como una crítica a tales leyes. Así aparece, por ejemplo en Schwantes: «Tales filigranas de nuestra obra de arte, tienen una función clara y nítida: cuestionar los sacrificios de niños al revelar la mentira que encierran (vv. 7-8), al sacar a la luz del día los contra-sentidos que constituyen (v. 6 en comparación con el v. 10), al denunciar la brutalidad de este acto (vv. 9-10)». M. Schwantes, «No extiendas tu mano contra el niño. Reflexiones sobre Génesis 21 y 22», op. cit., 41. Pero, aunque se cuestionan las leyes sacrificiales en sí mismas, no se va más allá, al no tomar en cuenta la lógica sacrificial de toda ley que sin ningún tipo de intervención (discernimiento) produce inevitablemente sacrificios.
} 
lógica sacrificial que está presente en la estructura misma de las leyes a las que se enfrenta la persona, sobrepasa el marco de las intencionalidades de quienes las promueven. La ley y su lógica trascienden dicha intencionalidad, porque las leyes, quienes las promueven, e incluso, las propias formas sacrificiales pueden variar a lo largo de la historia.

El análisis de la sacrificialidad debe ir más allá de esta dimensión particular y contextual de la ley, y trascenderla al considerar su aspecto general, esto es, que todo sometimiento irrestricto y absoluto a la ley deviene sacrificio. En Gn. 22, nos enfrentamos a un texto que rehusa la sacrificialidad y afirma que ninguna razón -ni de cumplimiento ciego de la ley, aún cuando se trata de la misma ley de los dioses tradicionalesresulta válida para el sacrificio. El argumento clave para ello es que un Dios de la vida no puede aceptar el sacrificio humano; pertenecerle a ese Dios, «significa vivir y no sacrificarle la vida por la muerte» ${ }^{47}$.

De aquí que, desde el punto de vista hinkelammertiano en gran medida utopista, incluso la propia negación al sacrificio -el «no al matar»- no pueda convertirse a sí misma en una ley o mandamiento particular en sentido estricto, siendo que la negación al sacrificio, está a la base y es anterior a todo mandamiento:

El No al matar no es un mandamiento. Si lo fuera, no habría ninguna novedad. Se trata más bien de la raíz, de la cual brota cualquier acción humana racional. Se trata de la afirmación de la vida humana misma, y esta afirmación es la única afirmación de la vida humana, que es efectivamente afirmación de la vida corporal humana. En el No al matar está la corporeidad, porque el matar es en sí la negación de la corporeidad ${ }^{48}$.

Ahora bien, este tipo de fe existencial y antropológica como la abrahámica encuentra su continuidad inmediata dentro de la religión judía en la llamada tradición mosaica, siendo su referente de positivación nomística. Sin embargo y como se sabe, la durabilidad y permanencia de esta tradición y línea abrahámico-mosaica de discernimiento no legalista de la ley, para el tiempo de Jesús ya es cuestionable. En lo que sigue se intentará comprender cómo se pro- 
duce el salto desde un estadio inicial de constitución de una ley dada para la vida, y por tanto potenciadora de la persona y facilitadora de la convivencia social, en continuidad con la fe abrahámica (tradición mosaica), hasta un proceso paulatino de institucionalización y dogmatización de la ley en el período postexílico.

\section{La tradición legal mosaica: reflexividad y don vs. legalismo}

No sería posible sostener la centralidad de la vida de la persona frente a la ley, desde la perspectiva hinkelammertiana, sin entrar a considerar la legalidad judía. Máxime, si se tiene en cuenta el especial significado de ésta en el judaísmo, lo que se atestigua por la comprensión histórica del Antiguo Testamento como «libro de la ley», dada la relevancia atribuida a la primera de las tres partes de canon veterotestamentario ${ }^{49}$. E igualmente por la preponderancia del estudio de los escritos legales del Antiguo Testamento -Gn., Ex., Lv., Dt., Jos., Sal.- en las sinagogas judías.

Sin embargo, en el abordaje de este tema, resultaría conflictivo tratar «la ley» como un concepto homogéneo. La ley para el judaísmo, pero de manera idéntica para muchas culturas del Oriente antiguo, se presenta como una multiplicidad compleja de «instrucciones dadas en casos particulares, como parte de una colección legislativa de reglas particulares o como parte de la práctica legal -ya no escriturariaejercida por el soberano o por los jueces» ${ }^{50}$.

Esta complejidad inherente a la ley, responde fundamentalmente a: (1) su disímil presencia espacio-temporal, esto es, la cuestión de la datación dispar desde los «catecismos» breves y el «libro de la alianza», durante la peregrinación por el desierto y la toma de Canaán, hasta las leyes cultuales en la comunidad postexílica; (2) el tipo de

49 Cf. M. Noth, Estudios sobre el Antiguo Testamento (Salamanca: Sígueme, 1985), 12.

50 P. Beauchamp, Ley, Profetas, Sabios. Lectura sincrónica del Antiguo Testamento (Madrid: Cristiandad, 1977), 41. 
formulación de las leyes, señalándose al menos dos: la formulación «casuística», referida a las leyes que plantean un caso hipotético y se introducen por un «si», luego de lo cual se determina la sanción para reaccionar ante dicho caso hipotético, y la formulación «apodíctica», que presenta una exigencia («harás/haréis») con validez absoluta sin posibilidad de ser cuestionada ${ }^{51}$; y (3) la variación de los contenidos legales, que incluyen desde regulaciones normativas de la vida cotidiana hasta exigencias sobre la participación cultual ${ }^{52}$.

Más allá de esta complejidad que le es propia, «la ley» aparece a lo largo de la tradición veterotestamentaria con una cierta especificidad. Se trata de una identidad y unidad de la ley al menos en dos sentidos. Primero, desde el punto de vista externo o formal, los diferentes estratos legales aparecen formando un bloque en el Hexateuco, mientras que leyes de muy diversa procedencia aparecen introducidas conjuntamente en los códigos veterotestamentarios. Esta visión de la unidad de la ley se hace evidente en Oseas, Isaías y particularmente en el Deuteronomio, y conduce a lo que anteriormente señalamos, esto es, al hecho de cómo torá se designe no solo al Pentateuco, sino incluso a todo el conjunto del canon veterotestamentario.

Segundo, podemos hablar de una identidad desde el punto de vista interno en cuanto a contenidos legales se refiere ya que idénticas sentencias normativas son reiteradas, una y otra vez, en narraciones diversas, repitiéndose los mismos temas legales. Pero también, porque no se podría establecer una tajante distinción entre derecho sagrado o cultual y derecho profano, en la medida en que estas esferas aparecen profundamente imbricadas, dado que para la mentalidad hebrea cada aspecto cotidiano de la vida guarda relación con lo cultual ${ }^{53}$. En síntesis, tanto a nivel de la forma -unicidad como bloque literario-, como de

Cf. A. Alt, citado por W. Schmidt, Introducción al Antiguo Testamento (Salamanca: Sígueme, 1993), 142. Cf. M. Noth, op. cit., 15-18.

En este sentido M. Noth señala lo inconveniente de usar la clásica distinción entre prescripciones cultuales y no cultuales (éticas, sociales, etc.), a la hora de clasificar las reglamentaciones legales judías. En su criterio, en el ambiente en el que se formulan las leyes veterotestamentarias no se distingue entre un terreno de actuación sacro y otro profano. Únicamente algunos catecismos breves tienen un contenido bien preciso y determinado. Ibíd., 64. 
contenido, los materiales referidos a «la ley» muestran una profunda articulación o conexión como conjunto. Noth puntualiza esta unidad en los siguientes términos: «dentro del Antiguo Testamento «la ley» representa algo específico que, a pesar de sus distinciones internas, aparece como una realidad típica, que puede y debe ser considerada como tal ${ }^{54}$.

Por la limitada extensión de este artículo, no se pretende penetrar en toda la amplitud de «distinciones internas» de esta «realidad típica» que es la ley en la comprensión judía. Se hará referencia primeramente a lo que se entiende como el sentido fuerte y originario de la ley israelita, esto es, la tradición de la ley mosaica, dada con el objetivo de viabilizar y garantizar la vida del pueblo, y por tanto, reflexiva frente a la vida de la persona concreta. Esta tradición legal mosaica se inicia con la formulación y estipulación de la ley sinaítica en la época tribal, llegando a dominar toda la expresión legal pre-exílica desde este período hasta la desaparición de los estados independientes de Israel y Judá. Sin embargo, al constituir una determinada tradición o eje interpretativo de la ley, se extiende mucho más allá de estas barreras espacio-temporales. En un segundo momento, se abordará el estadio de institucionalización y absolutización de la ley, que paulatinamente se va produciendo en lo que conocemos como la tradición legal postexílica dada en el contexto de los sucesivos imperios babilónico, persa, helénico y romano. En cada uno de estos dos momentos se mostrarán algunos de los elementos de conflictividad en torno a la ley y el necesario criterio de discernimiento frente a la ley, que es la vida de la persona corporal y concreta.

\subsection{Reflexividad de la tradición mosaica a partir de la vida humana}

La gran mayoría de los biblistas convergen en considerar la gestación de la ley mosaica en el período intermedio entre la experiencia del éxodo-conquista de Canaán y la creación del estado alrededor del 1300 al 1050 a. C, como un suceso de carácter subalterno. Lo 
central en la historia salvífica de este período recae en el hecho de que Dios ha escogido a Israel como su pueblo y le ha ofrecido gratuitamente unas promesas y una alianza, las cuales han sido asumidas por el pueblo. Por tanto, la ley y su cumplimiento aparecen como consecuencia de estos dones otorgados, como una respuesta natural de fidelidad para con el dios que les ha escogido y prometido la vida, una postura por demás, comúnmente aceptada en el Oriente antiguo. En otras palabras, la ley viene a ser resultado o expresión de una alianza que tendría preeminencia desde todo punto de vista; alianza indisolublemente vinculada a la historia misma de Israel ${ }^{55}$. Y la experiencia verdaderamente fundante o constitutiva del desierto vendría a ser la alianza del Sinaí, expresada en la fórmula: «Vosotros sois mi pueblo y yo soy vuestro Dios» (Ex. 6.7 $)^{56}$. El correlato de tal alianza, lo constituyen las formulaciones legales mosaicas, que en su forma esencial son el Decálogo y el llamado Código de la Alianza (Ex. 20.22-23.19) como corpus jurídico más antiguo de Israel. Noth así lo enfatiza: «es bastante claro que los antiguos estratos de la narración de Ex. 19-24 anteponen y sobreponen objetivamente el hecho de concertar la alianza, dándole más importancia que a la promulgación de leyes» ${ }^{57}$.

A la base de esta alianza y de las leyes subalternas que se derivan de la misma aparecen eventos o hechos históricos centrales para la vida de Israel en este período, y por tanto, fundamento de las leyes. Entre estos hechos que otorgan validez y fuerza a las leyes y explican históricamente la alianza, podemos mencionar: a) la salida de Egipto y entrada a la tierra prometida; b) el necesario ordenamiento socio-jurídico dentro de una organización comunitaria sagrada, anterior a toda ley, que es la agrupación de las doce tribus israelíes; c) el contacto y la adopción paulatina de principios jurídicos cananeos, que después se generalizaron en todo Israel; d) una profesión de fe histórico-cultual, existente ya desde la época antigua y que está a la base de la organización de las tradiciones y leyes. Estos eventos ubican el origen de las leyes israelitas tanto en la jurisprudencia ordinaria, necesaria en una organización social en ciernes (inicio de la vida sedentaria), bien sea por efecto mimético con los pueblos vecinos (cananeo, fundamentalmente), o por simple imposición práctica de la administración de la justicia en la cotidianidad, como en aquellas consideraciones de índole histórico-religiosas (profesión de fe, éxodo, p.e). Aun cuando existan diversos criterios sobre el evento que se ubica en la génesis de la ley, apenas hay discordancias sobre la subordinación de la ley y la alianza a cualquiera de estas realidades históricas. Cf. J. Pikaza, La Biblia y la teología de la Historia (Madrid: Fax, 1972), 64-69; M. Noth, op. cit., 40-50; W. Schmidt, op. cit., 143s.; G. von Rad, op. cit., 25-38.

56 Esta primera frase de la fórmula del Sinaí -elemento central o esencial del pacto-, es reiterada en la alianza que Dios establece con Abraham en Gn. 17. A diferencia del pacto sinaítico donde el compromiso entre Dios y su pueblo era mutuo, con el patriarca, en cambio, es solo Dios quien se obliga a sí mismo: sea cual fuere la respuesta y actitud que asuma el pueblo, se dice allí que el Señor será para siempre Dios de Abraham y de su pueblo. Cf. J. Pikaza, op. cit., 75 y 94s. 
Esta preeminencia de la alianza respecto de la ley no supone necesariamente una separación tajante entre ambas, ni la sucesión de la una respecto a la otra. Antes bien, es al interior de la alianza que la ley encuentra su sentido y razón de ser, ubicándose como momento intermedio, relacionada con los eventos de promesa y bendición, característicos de la alianza. Tal como lo expone Pikaza, «en el principio de todo está la promesa. En ella se trasluce la voluntad original de Dios. Para su realización se introduce, como un medio y un camino, la exigencia de la ley. Pero otra vez, en el fin, aparece de nuevo la promesa, como algo que se cumple en forma de bendición ${ }^{58}$.

La alianza sinaítica es ante todo una promesa que representa la voluntad salvadora de Dios para con la vida de su pueblo. Tal voluntad y acción gratuita de Dios a favor de la vida (promesa) se manifiesta como momento primero al que se subordinan las leyes ${ }^{59}$. Ello se argumenta bíblicamente desde la relación entre la promesa de dones para la vida (alimentos como maná, agua, tierra, salud, bienestar) y las leyes estipuladas, donde los primeros constituyen «el bien para todo hombre, es el bien común de todos los hombres (...). El Deuteronomio (...) califica sobre todo de «vida» esta recompensa de la ley» ${ }^{60}$. Tales dones son considerados una exigencia sine qua non de la estipulación de la ley, en tanto permiten la reproducción de la vida del pueblo ${ }^{61}$.

Dentro de esta concepción de una relación tan estrecha entre la ley y los ámbitos de la vida -relaciones interhumanas, sociales, culturales y de sentido, que hacen parte de la comprensión de la vida en el oriente antiguo-, resulta comprensible que la ley llegase

58 J. Pikaza, op. cit., 66. Énfasis de la autora.

59 Ibíd., 252.

60 P. Beauchamp, op. cit., 42.

61 El contenido material de los dones de vida imprescindibles para la supervivencia del pueblo, va a atravesar todo el conjunto legislativo del Antiguo Testamento: «Las leyes veterotestamentarias se preocupan de todos los aspectos de la vida, también de la vida diaria (...) con determinaciones sobre la relación entre el hombre y el hombre (protección de la vida, integridad corporal, defensa de la propiedad, derecho a la imparcial administración de la justicia, etc.); normas sobre el puesto del individuo dentro de las formas fundamentales de la sociedad humana (matrimonio, familia con patria potestas, etc.), importantes en las leyes y códigos del antiguo oriente (...) y precisas para la organización de la vida en el mundo histórico en que se mueven las tribus israelíes». M. Noth, op. cit., 64. 
a convertirse en «el todo» de Israel; un «todo» permanentemente atravesado por el movimiento de la vida. Tanto es así que, dentro de la tradición sinaítica se produce no solo una revisión de las leyes concretas mismas, sino también, y lo que es más importante, una vuelta perenne a la articulación de estas con su origen y su fin ${ }^{62}$. Aquello por y para lo cual las leyes garantes de vida han sido dadas, aparece siempre como un horizonte de sentido que orienta toda aplicación y reformulación legislativa. La vida -el estar con vida, transpirar vida-; su movimiento permanente en las relaciones sociales; los dones concretos de vida -tierra, vestido, alimento, familia, goce- de parte del Dios de Israel, quien se ha manifestado en el éxodo y en el desierto como única fuente de vida, son los argumentos teológicos que otorgan consistencia, autoridad y sentido a unas determinadas leyes ${ }^{63}$.

Lo relevante de la manera como Franz Hinkelammert concibe la ley mosaica es que no solo ubica, como hacen otros autores, a los dones de vida como ejes transversales que atraviesan y orientan las leyes concretas, sino que sitúa la propia ley mosaica en la lógica del don: al interpretarla como una ley reflexiva referente a la vida humana, la propia ley adquiere el carácter de dádiva gratuita garante de la vida, esto es, de don otorgado. En un extenso texto del capítulo primero de El grito del sujeto el autor madura este tema, interpretando la manera como Jesús concibe la ley mosaica. Inicia con una caracterización categórica: «Jesús interpreta la ley mosaica como una

63 Habría que destacar que para algunos exégetas, como fundamento último del criterio de vida que argumenta teológicamente a las leyes, aparece otro criterio a la base, que es la propia religión yahwista. A diferencia de los códigos jurídicos de los pueblos cananeos, las antiguas legislaciones israelitas se encuentran muy cercanas a la fe de Israel. «El libro de la alianza parte de una igualdad de derechos ante la ley y de la idea de una solidaridad común», que tiene sus raíces en el Yahwismo. Cf. G. von Rad, op. cit., 58. Es evidente que los propios contenidos jurídicos tienen un alto componente religioso al incluir como normas legales las obligaciones para con Dios, e incluso, al tratar las obligaciones recíprocas entre las personas, como demandas de parte de Dios. Las leyes que se ocupan de la convivencia social y las que están formuladas con el fin de regular las acciones cultuales, comparten no solo idénticos documentos, sino también una misma relevancia dentro de éstos. Cf. M. Noth, op. cit., 15-22. 
ley reflexiva referente a la vida humana. Es ley dada para la vida, y por tanto es una ley, que se interpela para la vida» ${ }^{64}$.

¿En qué radica la novedad de tal «reflexividad»? En el análisis del texto del amarramiento de Isaac (Gn. 22) nos movimos en un horizonte de ley, de tendencia inercial de tipo sacrificial, que exigía que externamente -desde las personas de Isaac y Abraham-, ésta fuera constantemente interpelada. Sin embargo, se trata ahora de una tradición legal que es «ley reflexiva», «dada para la vida»y que, por tanto, «se interpela para la vida». Tres lógicas novedosas, de reflexividad (frente a la vida), don (de vida) e interpelación (para la vida).

En primer lugar, se afirma que la ley mosaica es una ley reflexiva en lo que a la vida humana se refiere, esto es, que como ley está abierta a reconsiderar una y otra vez, con detenimiento y profundidad, todo cuanto esté relacionado con la vida humana. Ello está a tono con lo que Tamez entiende como la función y el carácter de la ley como «vehiculadora de vida concreta para todo ser humano necesitado de ella» ${ }^{65}$. Segundo, nos dice que una ley reflexiva es dada para la vida, lo que establece el sentido profundo de la ley mosaica y explica el por qué ha sido dada, esto es, para permitir y garantizar la vida humana, ubicando la propia ley como don de vida. La ley del Sinaí como expresión de la voluntad amorosa y gratuita de Dios (don) está al servicio de la vida de Israel. Lo que nos deja abierto el interrogante sobre si hay leyes que no sean dadas para permitir vivir ${ }^{66}$ y nos recuerda que aún cuando toda ley haga referencia a la vida, unas lo hacen de manera directa (como la que nos ocupa) y otras de manera muy indirecta; pero también unas afectan positivamente la vida humana y otras lo hacen negativamente. Tercero, nos dice que al ser una ley dada para la vida, necesariamente y "por tanto, se interpela para la vida». Quiere esto

\footnotetext{
64 F. Hinkelammert, El grito del sujeto, op. cit., 36.

65 E. Tamez, Contra toda condena. La justificación de la fe desde los excluidos (San José: DEI, 1991), 163.

66 Haciendo referencia a la legalidad hebrea el propio Hinkelammert en este apartado recrea el texto de Ez 20, 25-26, en el que el profeta Ezequiel admite que Dios alguna vez haya dado «preceptos que no eran buenos y normas con las que no podrían vivir», pero exclusivamente para producir horror en el ser humano.
} 
decir que, en este tipo de leyes, la interpelación es «interna» a la ley y no externa. O en otras palabras, que la ley en sí misma abre ya el espacio de la interpelación, el discernimiento, la demanda de explicación por su sentido y vigencia, aún cuando esta interpelación provenga siempre de la persona, puesto que la ley no se interpela a sí misma.

Todo ello referido no a unas leyes particulares únicamente (Decálogo/Código de la Alianza), sino a una «Concepción» global de la ley que funda una determinada tradición legal y óptica interpretativa de la ley. Es decir, una concepción legal que intenta ser reflexiva; unas leyes concebidas desde el principio ya abiertas a la interpelación (aunque exigida siempre a la persona que interpela); una comprensión de la ley que se opone a una concepción formalista de la ley que no concibe interpelación alguna y que por lo tanto debe ser interpelada siempre «desde fuera», lo que será ampliado más adelante.

El texto de Hinkelammert que estamos siguiendo, continúa: «Por eso, Jesús (...) puede insistir en que no ha venido para abolir la ley, sino para cumplirla, y que no va a quitar ni una jota de la Ley» ${ }^{67}$, lo que resulta corolario de lo anterior. Esta ley mosaica puede y debe cumplirse. Pero su legitimidad no descansa en la legalidad; ella no ha de cumplirse en forma legalista, es decir, por el simple hecho de ser ley formal, sino que ha de juzgarse su cumplimiento a partir de los resultados de la ley sobre la vida humana. Tal es lo que ocurre con la tradición mosaica: «las normas no valen por legalidad formal; son constantemente interpeladas en nombre de la vida humana ${ }^{68}$.

En el marco de una ley reflexiva que abre espacios de interpelación, interpelarla, discernirla, requerir una explicación sobre su lógica de funcionamiento, violarla en los casos en que la ley afecte la vida de las personas y por tanto se subvierta a sí misma, hace parte

67 F. Hinkelammert, El grito del sujeto, op. cit., 36.

68 Ídem. 
de su cumplimiento. Esta interpelación de la ley mosaica permite y obliga a adaptar la ley a situaciones y demandas concretas de la vida humana. Se trata de una ley reflexiva y flexible que no se cumple por el formalismo de las normas, sino que se ajusta a circunstancias específicas. De lo que da fe el Salmo 82 dirigido a los jueces, a quienes se les demanda aplicar la ley sin favoritismos para con los impíos ${ }^{69}$. En este texto, la justicia de los jueces estriba no en el cumplimiento de la ley, sino en que dentro de este marco hagan verdadera justicia al huérfano, la viuda, el pobre y el que sufre. La justicia -de los jueces y de toda persona- no está en el cumplimiento de la ley, porque no es la ley la que puede conseguir la justicia del ser humano ante Dios, ni la plenitud de vida en la tierra ${ }^{70}$.

Del mismo modo como la tradición de ley mosaica permite el discernimiento, la flexibilidad y adaptación de la ley a las situaciones concretas de la vida, así mismo obliga a suspender la ley cuando esta afecte la vida humana, en tanto se trata de una ley hecha para vivir: «La ley es para la vida, por tanto, hay que suspenderla para que sirva para la vida. La ley, en cambio, que no se suspende cuando sea necesario para que sirva a la vida, mata. Aplicar la ley sin juicio de discernimiento conduce a la muerte ${ }^{71}$. A la par de esta interpelación por parte del ser humano y de la potencial suspensión intrínseca a la ley, la propia concepción de la ley mosaica introduce normas que la autolimitan. Se trata de una interpelación a la ley desde dentro de sí, a partir de normas al interior de la ley:

Esta interpelación encuentra muchas veces otras expresiones normativas que limitan la norma formal originaria. Así por ejemplo con la norma del pago de la deuda. También la Ley mosaica prescribe el al débil, hagan justicia al pobre y al que sufre, (4) libren al indigente y al humilde, sálvenlos de las manos del impío. (5) Sin saber, ni entender, andan a oscuras, el piso de la tierra se conmueve. (6) Todos ustedes son dioses, les dije, y son también los hijos del Excelso. (7) Pero, como los hombres morirán, príncipes, caerán como un cualquiera. (8) Oh, Dios, ponte de pie, juzga la tierra, pues a ti pertenecen las naciones». Tomada de la Biblia Latinoamericana (Madrid: Paulinas, 1972).

70 Cf. J. Pikaza, op. cit., 203.

71 F. Hinkelammert, El grito del sujeto, op. cit., 36. 
pago de la deuda como norma formal. Pero, dado que esta norma, en su lógica, socava hasta la existencia de la comunidad humana, la interpela por otras normas que la limitan. Estas interpelaciones son, por ejemplo, la declaración de años de gracia, años sabáticos o años del jubileo, que le quitan a la norma formal su vigencia absoluta. (...) Toda la Ley mosaica está llena de reflexiones de la vida humana en referencia a normas formales a las cuales se quita la validez absoluta que les imputa el simple legalismo. Eso da a esta Ley muchas veces un carácter fuertemente casuístico, porque se interpelan unas leyes por otras. Pero lo que fundamenta esta casuística, es la reflexión de la vida humana frente a la Ley ${ }^{72}$.

En resumen, encontramos aquí, de acuerdo a nuestro autor, una tradición de ley mosaica reflexiva en varios sentidos: primero, una ley que es dada para la vida y se orienta por ese su canon; segundo, una ley que obliga a ser interpelada por la vida cuando la afecte; y tercero, una ley que refuerza este horizonte de interpelación introduciendo a su interior normas de corrección (autorreferencia de la ley). Se trata de un sistema legal que no pretende una reflexividad prescindiendo de la persona, pero que le ayuda a su interpelación, instaura la legitimidad de la interpelación y coadyuva a la interpelación con normas de corrección. No es el objetivo de este artículo definir la validez o no de esta concepción amplia de ley mosaica, sino solamente mostrar esta interpretación de la tradición desde sus vínculos internos con la vida de la persona ${ }^{73}$.

\subsection{Legalismo y absolutización de la ley mosaica}

72 Ídem.

73 Nos interesa resaltar el contraste entre esta interpretación de la tradición mosaica, con otras visiones. Así, por ejemplo, G. von Rad, asume que en este período se pasa por un «sometimiento a esas normas sagradas y colaboración personal en su realización» en tanto se trataba de «un pueblo incapaz de comprender el mundo si no es con categorías sagradas, es decir, a partir de leyes e instituciones sagradas que provenían del culto y se mantenían en vigor en virtud de los ritos (...) El hombre no podía entrar en contacto o participar del mundo divino sino sometiéndose a las normas sagradas que regulaban su vida social e incluso sus relaciones rurales con la naturaleza circundante. La transgresión voluntaria de este orden sacro suscitaba en aquellos tiempos el terror propio de una profanación cultual». G. von Rad, op. cit., 60s. Según esta hipótesis, la respuesta del israelita tribal estaba mediada por el temor y el sometimiento, y no por el hecho de tratarse de leyes con sentido («no matarás», etc.) que a todas luces garantizan la vida humana y que pueden ser asumidas en libertad y discernidas por el ser humano. 
Hemos analizado cómo en la tradición mosaica vigente hasta el exilio la ley había sido considerada un evento subordinado al pacto y a las promesas de vida. Con la caída de Jerusalén en el año 586 a. C, «esa ley y el pacto que la vivifican son devaluados, pierden su vigencia. Ha terminado el orden antiguo de cosas y no queda sino el recuerdo de las pasadas grandezas ${ }^{74}$. Después del exilio, con el cambio de las condiciones de vida, muchas leyes propias de la tradición sinaítica pierden su sentido original y otras que son añadidas -tales como las disposiciones cultuales davídicas- se van convirtiendo progresivamente en preceptos religiosos artificiales ${ }^{75}$. Las leyes concretas se alejan cada vez más de su primigenio carácter de don para la vida, en la medida en que ya no aparecen como consecuencia o expresión de un pacto y unas promesas para garantizar la vida de un pueblo. La ley se cierra sobre sí, se transforma en un valor en sí misma y pasa a ser una regulación formal de las acciones humanas.

La ley se convierte en valor autónomo, sin presupuestos temporales, sin un antes o un después en la historia de la salvación, como absoluta e inmutable voluntad divina. Más que «ley» podría hablarse ahora de un conjunto de normas e imposiciones que Dios con su autoridad ha sancionado. Estas leyes poseían antes valores distintos (...). Ahora toman todas ellas la misma importancia, aún aquellas que han perdido su sentido original al separarse del contexto antiguo en que surgieron. Desde ahora el hombre religioso deberá estudiar la «ley» e interpretarla; en ella se encierran todos los misterios que Dios ha querido revelarnos. Nace con esto la figura del doctor de la ley o escriba. Dios ha dejado de hablar directamente ${ }^{76}$.

Se produce así, una inversión de la relación entre la ley y la vida en Israel. Si en la tradición originaria la ley se subordinaba y servía a la vida, ahora el propio Israel subordina su vida social y cotidiana

76 Ibíd., 203. Esta concepción de la ley se hace particularmente evidente en las últimas obras cronistas del siglo III a. C. (Crónicas, Esdras-Nehemías). «El cronista, en un intento de precisar la historia completa de Israel, proyecta aquello que tiene validez definitiva en el presente: la ley y el templo. Para el cronista lo importante no es el don divino de la tierra (Palestina) dada a Abraham y sus hijos, sino que lo que tienen valor son los mandatos de Dios, que deben ser cuidadosamente observados (1 Cron. 28.8). Por no cumplirse ha llegado el castigo del destierro. Dios perdona y hace volver a su tierra a los cautivos, pero ahora deben cumplirse con todo cuidado sus leyes». Ibíd., 204s. 
a una ley que demanda obediencia ciega. Es en el cumplimiento de lo que ella ordena que residirá el sentido y la plenitud de la vida. La flexibilidad y adaptación de la ley sinaítica a circunstancias concretas de la vida en sintonía con el tiempo, lugar y la manera de ser del pueblo se interrumpe, para ceder paso a una nueva manera de concebir la ley y, por ende, a una nueva tradición. Se trata de una tradición legalista dentro de la cual, como plantea von Rad, «la ley se convierte en una realidad absoluta con validez incondicional, independiente del tiempo y de la historia» ${ }^{77}$.

Se llega al grado, llamado nomismo, cuando pierde vigor la necesidad que dio origen a las prescripciones. En este caso las leyes dejan de ser una expresión de las exigencias que la comunidad cultual encuentra inevitablemente en su vida, más aún, aparecen extrañas e independientes frente a la vida y ésta, que las produjo, no estará ya con ellas por mucho tiempo; se quedan ahí con su rígida autoridad y se convierten en mandamientos que deben ser observados precisamente por ser mandamientos autoritarios. Lo que en un tiempo nacía del interior se cambia en algo que le viene a la persona desde afuera ${ }^{78}$.

En otras palabras, se llega al grado de institucionalización ${ }^{79}$ y formalización de la ley. El nuevo formalismo legal impregna a la ley de un sello dogmático. La ley se transforma en dogma en la medida en que se presenta con una determinada forma fija y un contenido

G. von Rad, op. cit., 130 .

R. Asting, citado por von Rad, Ídem. (Énfasis de la autora). Las consecuencias de esta transformación son al menos tres: (1) Cambia la manera en que Israel se concibe como pueblo. Si en la tradición mosaica reflexiva Israel es considerado como una comunidad natural e histórica, esto es, un pueblo en el sentido propio de la palabra, en el post-exilio la propia ley empezó a determinar quién pertenecía o no a Israel. (2) Solo cuando Israel comienza a concebir la "palabra viva de Dios» Como ley normativa es que se puede decir en propiedad que aparece el fenómeno del judaísmo: Israel se priva de la solidaridad para con otros pueblos y de hecho se mantiene al margen de las otras naciones, convirtiéndose en un pueblo inquietante para éstas. (3) Como resultado aún más dramático de esta nueva comprensión de la ley, Israel sale de la historia vivida hasta aquí. Una vez que comienza a considerar la voluntad de Yahweh de manera atemporal (ya no sujeta a las circunstancias de vida del pueblo), Israel deja de vivir y hacer historia, y no volverá a hacerlo hasta el tiempo de los Macabeos. Cf. G. von Rad, op. cit., 129ss.

79 Conviene distinguir entre la legalidad mosaica como institución social propia del judaísmo, de este proceso que llamamos «institucionalización». La ley como institución abierta, promotora y garante de la vida de Israel, y como tal, siempre creativa y dinámica (carácter «instituyente» de una ley dada para la vida), se institucionaliza en tanto estructura o sistema cerrado (lo «instituido»). Esta nueva institucionalidad se expresa en códigos estáticos, impersonales e impuestos por fuerza. Cf. J. Pikaza, Sistema, libertad, iglesia. Instituciones del Nuevo Testamento (Madrid: Trotta, 2001), 17-25. 
inalterable ${ }^{80}$. Esta tradición formalista de la ley, según Hinkelammert, «pretende tener validez exclusivamente por el cumplimiento formal de su legalidad, independientemente del efecto de este cumplimiento sobre la vida humana. Ha llegado a ser ley, que es considerada legítima por su legalidad $»^{81}$.

La validez de esta ley es afirmada apriorísticamente desde el legalismo: «legitimidad por legalidad $»^{82}$. La ley se hace legítima por su propio estatuto legal y jurídico; se hace suficiente en sí misma y por tanto, afirma su cumplimiento como norma formal, de manera absoluta. No importa cuáles sean las consecuencias del cumplimiento de la ley sobre la vida humana: cumplirla justifica cualquier resultado. En este sentido, la ley se manifiesta como ley de cumplimiento y deviene irresponsable frente a los resultados que produce en la vida de las personas sobre quienes actúa.

Ya no hay responsabilidad por los resultados, sean estos malos o buenos. La ley se hace irresponsable. Se legitima el cumplimiento de la ley por su propio cumplimiento. La ley se hace tautológica. Traducido al lenguaje bíblico, el principio de Max Weber dice: el ser humano es para el sábado, y no el sábado para el ser humano. En el caso de la ley del valor eso desemboca en el principio del precio justo como el precio que se da en el mercado y que es justo precisamente, porque se da en el mercado. Las consecuencias sobre la vida humana son irrelevantes, y el sistema se rige por la más completa irresponsabilidad ${ }^{83}$.

Para el autor, este carácter tautológico o cerrado de la ley en sí misma se manifiesta con toda claridad en la ley del mercado. Cualquier imposición indiscriminada del mercado y sus políticas, tienen su legitimidad y validez en el propio sistema de mercado: las tasas de intereses, el cobro de la deuda externa y los ajustes estructurales

80 En este proceso de dogmatización de la ley actúan como mediadores los sacerdotes. De hecho, la instrucción en la Torá comenzó a constituir una de las funciones esenciales del sacerdocio una vez que monopolizan el dominio de la ley. Cf. G. von Rad, op. cit., 257ss. Los sacerdotes son acusados de haber olvidado la Torá de Yahweh (cf. Os. 4.6), de haber hecho caer a muchos israelitas por medio de la falsa Torá, y de abusar de la Torá (cf. Mal. 2.8). Cf. C. Westerman, op. cit., 1292.

81 F. Hinkelammert, El grito del sujeto, op. cit., 36s.

82 Hinkelammert asume la frase de Max Weber respecto del Estado de Derecho, en el cual desaparece la despotía del poder, pero se instaura una despotía de la ley como otro tipo de dominación, ahora de tipo legal.

Ibíd., 115 
como el recientemente aplicado en Grecia, no son cuestionados en tanto significan y reportan un determinado resultado para la vida social y económica de los pueblos, sino que se dan en el marco de legitimidad de las leyes del mercado.

Desde este punto de vista una ley cerrada sobre sí misma e impuesta por la vía legalista, termina siendo despótica, irresponsable y violenta para con la vida humana. La lógica de esta ley no está atravesada por el criterio de centralidad y preeminencia de la persona como señal inequívoca de la presencia y gratuidad de Dios allí donde la ley actúa. Por ello, Hinkelammert afirma: «La ley es violenta, y detrás de ella acecha el pecado. Destruye al ser humano y lo envuelve en la gran mentira, según la cual la ley salva como ley de cumplimiento legalista ${ }^{84}$. Se trata de una violencia que se da en el cumplimiento ciego de la ley, y se manifiesta en que se impone a los seres humanos sin que a su vez estos puedan decidir o discernir su cumplimiento o no.

La ley no mata porque sea una ley que exprese una obligación a matar. La ley mata por su forma, la ley produce el pecado no a partir de la transgresión de la ley, sino por imponer su vigencia de ley en nombre de su legalidad. Pero eso es también la fuente de la violencia ilimitada. Esta violencia no aparece a partir de la transgresión de la ley, sino es otra vez el producto de su forma legalista. En el curso de su cumplimiento formal, la ley mata ${ }^{85}$.

Según esta interpretación no resulta necesario que el contenido explícito y material de la ley esté en función de la muerte, lo que sería el caso de las leyes injustas que por sus propios contenidos re-

84 Ibíd., 40. La asociación entre pecado y ley es entendida por Beauchamp como «debilidad» de la ley: «La debilidad de la ley consiste en ignorar su debilidad: aquí, debilidad y ley nacen en el mismo lugar. (...) Aparece un lado común a la Ley y la gracia y otro común a la Ley y al pecado. (...) La ley está asociada al fracaso de la ley desde la primera generación, lo que constituye una nueva dificultad para creer que el pueblo recibió la tierra a cambio de la observancia de la ley». P. Beauchamp, op. cit., 49s. El término «debilidad» así usado guardaría relación con lo que San Pablo reconoce como la «maldición» que pesa sobre la ley. Cf. Gal. 3, 10-14.

85 Ídem. Cursivas de la autora. El autor ejemplifica lo expresado a partir del tema del pago de la deuda en el tiempo de Jesús, época en la que el deudor que no podía pagar perdía todos sus bienes y él, junto a toda su familia, eran vendidos como esclavos. Lo mismo sucedía en la Edad Media europea cuando todo deudor que no pagara recibía cárcel de por vida, en caso de que alguien no asumiera la deuda y pagara por él. Hinkelammert traslada el símil hasta nuestros días cuando pueblos enteros son condenados al hambre a causa de su deuda impagable. 
sultan en la destrucción de las personas y la naturaleza. No se trata de que una ley exprese esa "obligación a matar»; sino del hecho de que la ley puede contener ya dentro de sí el germen de la inhumanización y despersonalización toda vez que pierde su referencia a la vida humana.

\section{Conclusiones}

El análisis bíblico-teológico de raíz hinkelammertiana que se ha querido mostrar aquí sobre la relación entre la persona y la ley, ha partido del abordaje de los paradigmas veterotestamentarios abrahámico y mosaico pre-exílico, y ha buscado comprender el proceso complejo de separación de la tradición legalista judaica del criterio de vida, don y gratuidad por el que fue instituida. Ambos momentos y perspectivas histórico-analíticas de la ley, esto es, la perspectiva de una ley reflexiva dada para la vida y susceptible de ser internamente discernida por la persona autónoma, y la perspectiva de una ley institucionalizada, absolutizada, no abierta al discernimiento e impuesta heterónomamente a la persona, han sido abordadas con la intención de mostrar dos aristas y tradiciones divergentes de la relación entre la persona y la ley. En la primera de ellas, la persona, su humanidad plena, sus necesidades vitales y su existencia, resultan criterios de ultimidad a partir de los cuales juzgar el cumplimiento y vigencia de la ley; en la segunda perspectiva, la imposición formalista y ciega de la ley impide su discernimiento por parte de los seres humanos y grupos sociales y puede conducir a la injusticia, violencia y destrucción de la persona, lo que teológicamente se ha expresado aquí como "pecado» cometido en el cumplimiento legalista, ciego, impuesto, no discernido, de la ley.

En las sociedades contemporáneas, tal dimensión del pecado aparece cuando la ley se cumple en forma legalista, afectando y violentando la vida concreta de las personas. No ocurre por el simple cumplimiento de las leyes sociales per se, dado que éstas resultan necesarias para garantizar la vida y viabilizar las relaciones sociales. 
El pecado se produce cuando la institucionalidad formal, los aparatos de legalidad, la cultura, la sociedad y finalmente, las propias personas, dejan de tratar la ley como una ley que ha sido dada justamente para garantizar la vida y se elimina el criterio de humanidad plena y dignidad de la persona como fuente de discernimiento, relativización e intervención de la ley.

En esto se muestra no solo que el criterio de ultimidad sobre la ley es la persona humana, sino también el hecho de que la interpelación y reflexividad sobre la lógica y dinamismo de la ley han de provenir siempre de la propia persona -sujeto y actor social-como esa instancia última del discernimiento e interpretación de la ley. Es a la persona individual y social, consciente y autónoma a la que corresponde permanente y reflexivamente preguntarse en qué medida la ley y su aplicación está permitiendo y garantizando la vida de todos y todas. En otras palabras, preguntarse por el tipo de relación que se establece con la ley o de qué manera está siendo tratada y cumplida la ley, tomando en cuenta su referencia o no a la vida humana y la posibilidad de ser discernida, aplicada o suspendida por parte de la persona, atendiendo al criterio de vida.

El paradigma abrahámico de suspensión-violación de la propia ley de dios (en este caso, la ley del sacrificio del primogénito) pone de relieve que el criterio del discernimiento sobre las leyes ha de partir de la propia persona y que la proveniencia y carácter mismo de la ley (leyes constitucionales, leyes democráticas, leyes eclesiales, leyes consensuadas, etc.) no es garante de la aplicación justa o injusta de la ley. Aun cuando se trate de leyes justas, si son comprendidas y aplicadas como leyes de cumplimiento formal y legalista, sin tomar en cuenta la vida concreta de las personas, pueden producir y conllevar sacrificialidad y destrucción de la vida.

Ello no le resta vigencia y relevancia a las normas justas, como lo constituyen los grandes pilares jurídicos de las sociedades pluralistas modernas: pactos, convenciones, constituciones, legislaciones y declaraciones internacionales como la Declaración de las Naciones Uni- 
das (26 de junio de 1945) o la Declaración Universal de los Derechos Humanos (10 de diciembre de 1948). Tampoco resta legitimidad a otro pilar fundante de tales convenciones modernas occidentales: el «no matarás» de la tradición mosaica fundante en el Dacálogo. Aún cuando su cumplimiento pleno y cabal, de facto sea imposible, el mandamiento mantiene su vigencia como tal ${ }^{86}$. Se trata de toda una tradición legal y por tanto, de leyes justas, cuyo sentido de equidad, rectitud y respeto a la vida no es cuestionado; vigentes aún cuando su cumplimiento no sea del todo factible; y legítimas por su contenido ${ }^{87}$. Pero leyes que aunque sean justas y puedan ser asumidas plena y conscientemente por los seres humanos, pueden llevar a la muerte en cuanto se traten como formalismo legal. Si ello aplica, como en el texto de discernimiento abrahámico, a la propia «ley de Dios» modelo de ley para la vida, cuánto más aplica para toda ley que por su cumplimiento legalista no sea susceptible de discernir por la persona autónoma, libre y consciente: «Si la Ley mosaica no salva por cumplimiento, entonces ninguna ley lo hace. Porque (...) la Ley mosaica es ley de Dios, es el paradigma de toda ley. (...) Una crítica a la ley que sea válida frente a la Ley mosaica, necesariamente es válida para toda ley, venga de donde venga» ${ }^{88}$.

Con esta lectura e interpretación de la relación entre la persona y la ley desde la perspectiva bíblico-teológica no se pretende tampoco invisibilizar o minimizar las diferencias insalvables entre las diversas interpretaciones y abordajes de las relaciones prototípicas de sometimiento o discernimiento del ser humano respecto a la legalidad vigente. De hecho, en la propia lectura de Gn. 22 nos enfrentamos a dos tipos de pruebas, dos tipos de fe y dos relaciones distintas con la ley del sacrificio del primogénito. En ninguna de las dos hay sacrificio, pero

86 Se trata de la vieja discusión entre las factibilidades y la legitimidad y vigencia teórico-práctica de las normas.

87 Hinkelammert plantea la legitimidad de las leyes de Dios no a partir de su procedencia, sino a partir de los contenidos materiales de las mismas: «íTiene Dios el derecho de dar cualquier ley que se le antoje? Entonces sería un Dios déspota y arbitrario. Desde el punto de vista de los seres humanos, creados por él, no tendría ninguna legitimidad. Muy diferente es el 'no matarás'. Sería una prohibición con sentido, que puede ser asumida en libertad por el ser humano». F. Hinkelammert, El nihilismo al desnudo (Santiago de Chile: Lom, 2001), 112.

F. Hinkelammert, El grito del sujeto, op. cit., 194. Cf. Ibíd. 39s. 
en una de ellas hay la disposición (léase, intencionalidad) a sacrificar y esta disposición al sacrificio, vista como mérito, es la medida de la prueba. En la otra, la interpretación que se fue siguiendo, la negación al sacrificio aparece como el criterio de la fe y de la superación de la prueba. En esta última se hace presente un punto de vista que por siglos ha estado silenciado bajo el peso de las interpretaciones tradicionales de obediencia-sujeción-sometimiento de la persona a la ley.

En nuestro criterio, esta perspectiva hinkelammertiana y este abordaje de sentido del texto, resulta plausible y comprensible desde el punto de vista de una fe cristiana humanista. Es un texto ilustrativo y paradigmático del conflicto entre la vida humana y la ley, cuya actualidad es incuestionable. El tema de la sacrificialidad de la ley adquiere relevancia a partir de las experiencias sacrificiales vividas por la humanidad en el pasado siglo, de una magnitud sin igual en la historia humana y que se hacen presentes en nombre de leyes históricas, sociales y económicas sacralizadas, las cuales se extienden aún a los conflictos bélicos, políticos, económicos y civiles de la segunda década del siglo xxi. Hoy, la humanidad se enfrenta a gravísimos problemas de exclusión, violencia y destrucción de la naturaleza, al amparo de leyes totalizadas, que ponen en riesgo la propia sobrevivencia humana.

Si hoy queremos ponernos al lado de la víctima, por fuerza debemos recuperar esa fe de Abraham (...). Es una fe existencial, vital, inmediata, que tiene que inspirar las confesiones de fe que hagamos. (...) Se necesita fe para poder reivindicar la libertad. Hoy, todo un mundo está amenazado de ser sacrificado en nombre de la ley de la historia, que se formula como ley del mercado. Se necesita afirmar la libertad para imponerse a esta ley y asegurar la vida humana, para que ella no sea sacrificada. Hoy todo el mundo es Isaac, no obstante el victimario no se quiere reconocer como Abraham: ser humano libre que rechazó sacrificar a su hijo por tener fe, y con el cual Dios estableció la alianza sobre la base de esta $\mathrm{fe}^{89}$. 


\section{Bibliografía}

Barton, J., ed. La interpretación bíblica hoy. Santander: Sal Terrae, 2001.

Beauchamp, P. Ley, Profetas, Sabios. Lectura sincrónica del Antiguo Testamento. Madrid: Cristiandad, 1977.

Biblia de Jerusalén. Bilbao: Desclée de Brouwer, 1978.

Duque, J. y Gutiérrez G., eds. Itinerarios de la razón crítica: Homenaje a Franz Hinkelammert en sus 70 años. San José: DEI, 2001.

Duquoc, Ch. Cristología. Ensayo dogmático sobre Jesús de Nazaret el Mesías. Salamanca: Sígueme, 1992.

Ferrater Mora, J. Diccionario de Filosofía. Barcelona: Ariel, 1998.

Floristán, C. y Tamayo, J. J., eds. Conceptos fundamentales del cristianismo. Madrid: Trotta, 1993.

Gottwald, N. La Biblia Hebrea. Una introducción socio-literaria. Barranquilla: Seminario Teológico Presbiteriano y Reformado, 1992.

Graves, R. y R. Patai. Los mitos hebreos. Madrid: Alianza, 2000.

Habermas, J. Aclaraciones a la Ética del Discurso. Buenos Aires: Libros Tauro, 2000.

Hinkelammert, F. El nihilismo al desnudo. Los tiempos de la globalización. Santiago de Chile: LOM, 2001.

. El grito del sujeto. Del teatro-mundo del evangelio de Juan al perro-mundo de la globalización. San José: DEI, 1998.

. Cultura de la esperanza y sociedad sin exclusión. San José: DEI, 1995.

. Sacrificios humanos y sociedad occidental: lucifer y la bestia. San José: DEI, 1991. 
. La fe de Abraham y el edipo occidental. San José: DEI, 1989.

Ladaria, L.F. Introducción a la antropología teológica. Navarra: Verbo Divino, 2004.

Moltmann, J. Antropología cristiana en los conflictos del presente. Salamanca: Sígueme, 1980.

Noth, M. Estudios sobre el Antiguo Testamento. Salamanca: Sígueme, 1985.

Pannenberg, W. El hombre como problema. Barcelona: Herder, 1976. . Antropología en perspectiva teológica. Salamanca: Sígueme, 1993.

Pikaza, J. Diccionario bíblico. Historia y Palabra. Estella: Verbo Divino, 2007.

. Sistema, libertad, iglesia. Instituciones del Nuevo Testamento. Madrid: Trotta, 2001.

. La Biblia y la teología de la Historia. Madrid: Fax, 1972.

Rouiller, G. y P. Ricoeur, eds. Exégesis. Problemas de método y ejercicios de lectura. Génesis 22 y Lucas 15. Buenos Aires: La Aurora, 1978.

Ruiz de la Peña, J. L. Imagen de Dios: antropología teológica fundamental. Santander: Sal Terrae, 1988.

Scola, A. Cuestiones de Antropología teológica. Madrid: BAC, 2000. . Antropología teológica. La persona humana. Valencia: Edicep, 2003.

Schillebeeckx, E. Cristo y los cristianos. Madrid: Cristiandad, 1982.

Schmidt, W. Introducción al Antiguo Testamento. Salamanca: Sígueme, 1993.

Schwantes, M. La familia de Sara y Abraham. Caracas: Acción Ecuménica, 1993. 
. «No extiendas tu mano contra el niño. Reflexiones sobre Génesis 21 y 22», RIBLA 10, (1991): 27-45.

Sicre, J. L. Introducción al Antiguo Testamento. Estella: Verbo Divino, 2000.

Tamez, E. Contra toda condena. La justificación de la fe desde los excluidos. San José: DEI, 1991.

Biblia Latinoamericana Madrid: Paulinas, 1972.

Vidal, C. El legado del cristianismo en la cultura occidental. Madrid: Espasa Calpe, 2000.

Von Rad, G. Teología del Antiguo Testamento. Salamanca: Sígueme, 1993.

Westermann, C. El Antiguo Testamento y Jesucristo. Madrid: Fax, 1985. 